\title{
Interactive Comorbidity between Opioid Drug Abuse and HIV-1 Tat
}

\section{Chronic Exposure Augments Spine Loss and Sublethal Dendritic Pathology in Striatal Neurons}

\author{
Sylvia Fitting, ${ }^{*}$ Ruqiang $\mathrm{Xu}^{\dagger}{ }^{\dagger}$ Cecilia Bull, ${ }^{\dagger}$ \\ Shreya K. Buch, ${ }^{\ddagger}$ Nazira El-Hage, ${ }^{*}$ Avindra Nath, ${ }^{\S}$ \\ Pamela E. Knapp, ${ }^{* \dagger}$ and Kurt F. Hauser ${ }^{*}$ \\ From the Departments of Pharmacology \& Toxicology," and \\ Anatomy \& Neurobiology, ${ }^{\dagger}$ Virginia Commonwealth University, \\ Medical College of Virginia Campus, Richmond, Virginia; the \\ Department of Neurology, Johns Hopkins University, Baltimore, \\ Maryland; and the Department of Anatomy and Neurobiology, \\ University of Kentucky College of Medicine, Lexington, Kentucky
}

HIV-1 infection predisposes the central nervous system to damage by opportunistic infections and environmental insults. Such maladaptive plasticity may underlie the exaggerated comorbidity seen with HIV-1 infection and opioid abuse. Although morphine and HIV-1 Tat synergize at high concentrations to increase neuronal death in vitro, we questioned whether chronic low Tat exposure in vivo might contribute to the spectrum of neuropathology through sublethal neuronal injury. We used a doxycycline-driven, inducible, HIV-1 Tat transgenic mouse, in which striatal neuron death was previously shown to be absent, to examine effects of differential Tat expression, alone and combined with morphine. Low constitutive Tat expression caused neurodegeneration; higher levels induced by 7 days of doxycycline significantly reduced dendritic spine numbers. Moreover, Tat expression widely disrupted the endogenous opioid system, altering $\mu$ and $\kappa$, but not $\delta$, opioid receptor and proopiomelanocortin, proenkephalin, and prodynorphin transcript levels in cortex, hippocampus, and striatum. In addition to markedly reducing spine density by itself, morphine amplified the effect of higher levels of Tat on spines, and also potentiated Tat-mediated dendritic pathology, thus contributing to maladaptive neuroplasticity at multiple levels. The dendritic pathology and reductions in spine density suggest that sustained Tat \pm morphine exposure un- derlie key aspects of chronic neurodegenerative changes in neuroAIDS, which may contribute to the exacerbated neurological impairment in HIV patients who abuse opioids. (Am J Patbol 2010, 177:1397-1410; DOI: 10.2353/ajpath.2010.090945)

Exposure to HIV results in neurodegenerative alterations in the central nervous system (CNS) of a substantial proportion of patients, even in the era of highly active anti-retroviral therapy. Highly active anti-retroviral therapy does not readily cross the blood-brain barrier, making the CNS a safe-haven for infection, and permitting ongoing degenerative changes even when viral titers are quite low in the periphery. ${ }^{1-6}$ There is considerable evidence, both in patients and in experimental models, that coexposure to abused opiate drugs can hasten the onset and worsen the outcome of HIV encephalitis and other neurodegenerative changes. ${ }^{7-15}$ A more limited number of studies show that opioids increase viral loads, and hasten disease progression and/or neuropathology in simian immunodeficiency models, ${ }^{16-19}$ although this has been controversial. ${ }^{20-22}$ Our in vitro work has consistently shown evidence for interactions between Tat or gp120 and morphine that accelerate neurodegeneration. These interactive effects appear to be orchestrated by glial cells, ${ }^{23}$ and likely involve synergistic upregulation of proinflammatory chemokine/cytokine release and production of reactive species. ${ }^{24-26}$

The present work was undertaken to extend previous results suggesting that HIV-1 Tat exposure might disrupt endogenous opioid and chemokine signaling. ${ }^{10,24,27}$ Addi-

Supported by The National Institute on Drug Abuse (P01 DA19398; R01 DA18633; R01 DA24661; K02 DA027374).

Accepted for publication May 6, 2010

Address reprint requests to Kurt F. Hauser, Ph.D., Dept. Pharmacology and Toxicology, Virginia Commonwealth University, Richmond, VA 23298 E-mail: kfhauser@vcu.edu. 
tionally, we tested for subtle neuropathological changes that might be caused by HIV-1 Tat and opiate interactions since neuron death (terminal deoxynucleotidyl transferase-mediated dUTP nick-end labeling) was not observed in our previous study. ${ }^{14}$ Wild-type and transgenic mice expressing HIV-1 Tat ${ }_{1-86}$ regulated by a doxycycline (DOX) inducible, glial fibrillary acidic protein (GFAP) promoter were continuously treated with placebo, morphine, and/or naltrexone (s.c. implants) $\pm \mathrm{DOX}$ for 2,7 , or 10 days. Tat protein was detected by both immunostaining and western blotting in transgenic brain, and there was evidence of constitutive promoter activity. Immunoprecipitation was used to show the tendency of Tat ${ }_{1-86}$ from both exogenous and endogenous sources to form multimers. Tat induction \pm morphine caused sustained elevations in monocyte chemotactic protein (MCP)-1 (CCL2), regulated on activation normal T cell expressed and secreted (RANTES; CCL5), and interleukin (IL)-6 protein levels in the striatum, as previously shown in vitro. ${ }^{24} \mathrm{Co}$-exposure to Tat and morphine induced several parameters of injury assessed in Golgi-impregnated medium spiny neurons, including reductions in spine density, increases in dendritic varicosities or "beading," and increased incidence of dendrite fragmentation. Co-exposure to morphine significantly increased dendrite pathology caused by Tat. We also found that Tat induction by itself had profound effects on the expression of endogenous $\mu$ - and $\kappa$-opioid neuropeptides and receptors. Our results indicate that Tat intrinsically causes glial inflammation and sublethal changes in neuron structure, and further show that opiates exacerbate glial reactivity and neuronal injury through interactions with Tat. Additionally, and very importantly, Tat appears to alter endogenous opioid signaling activity in unexpected ways that may influence viral effects and interactions with exogenous opiates.

\section{Materials and Methods}

\section{HIV-1 Tat Transgenic Mouse Model}

All studies used a transgenic mouse line in which HIV-1 Tat $_{1-86}$ is expressed in a brain-specific, inducible manner. The generation of the line (Dr. Avindra Nath, The Johns Hopkins Univ. and Dr. Ashok Chauhan, Univ. South Carolina) has been detailed previously. ${ }^{10,14} \mathrm{~A}$ tetracycline (tet) "on" system was used for generation of inducible constructs. HIV-1 Tat ${ }_{1-86}$ (IIIB) was cloned downstream of a tet-responsive element (TRE) in the pTREX vector (Clonetech, Mountain View, CA). ${ }^{28}$ By crossing founders that express the TRE-Tat gene with mice engineered to express a GFAP promoter-driven reverse tetracycline transactivator, we obtained mice that would express HIV-1 Tat $_{1-86}$ in astroglia throughout the brain when induced with doxycycline (DOX). Inducible Tat transgenic mice express both the GFAP-reverse tetracycline transactivator and TRE-Tat genes, while control Tat(-) mice express only the GFAP-reverse tetracycline transactivator gene.
All animal procedures were approved by the Virginia Commonwealth University Institutional Animal Care and Use Committee. Adult, 2- to 6-month-old, male and female mice were kept on a 12 hours light/12 hours dark cycle with free access to food and water. Mice were randomly assigned to experimental groups. Some Tat $(+)$ and Tat(-) mice had standard mouse chow replaced with a specially formulated chow containing $6 \mathrm{mg} / \mathrm{g}$ DOX (Harlan, Indianapolis, IN) to induce Tat expression in the Tat(+) mice and to evaluate any nonspecific actions of DOX ingestion in the Tat(-) mice. DOX chow was administered for 2, 7, or 10 days in different experiments. A previous study reported increased astrocyte activation as well as elevations in caspase-3 after only 2-day DOX exposure. ${ }^{14}$ In mice that also received morphine and/or naltrexone, DOX feed was started the night before opiate administration to allow blood levels of DOX to stabilize. In the remainder of the manuscript, the DOX-exposed Tat $(+)$ and Tat $(-)$ mice are referred to as Tat $(+)^{\mathrm{DOX}}$ and Tat $(-)^{\mathrm{DOX}}$, respectively.

\section{Opiate Administration}

Morphine administration was achieved by subscapular implantation of continuous, time-release $25 \mathrm{mg}$ pellets (NIDA, Rockville, MD) under aseptic conditions and isoflurane anesthesia as described. ${ }^{29}$ Although $25 \mathrm{mg}$ morphine pellets are reportedly depleted at a rate of 5 $\mathrm{mg} /$ day, steady-state concentrations of morphine are measured in $\mathrm{ng} / \mathrm{ml}$ and differ among tissues. For example, $75 \mathrm{mg}$ morphine pellets typically yield steady-state levels of $\sim 22 \mu \mathrm{g} / \mathrm{ml}$ of plasma in C3HeB mice, and much of this includes conjugated morphine. ${ }^{30}$ Pellets without morphine were implanted in controls. Naltrexone was administered to mice via Alzet minipumps also implanted subcutaneously into the subscapular region. Sixty mg/ $100 \mu \mathrm{l}$ naltrexone solubilized in 50\% DMSO was used to fill 1007D model pumps $(0.5 \mu \mathrm{l} / \mathrm{h}$ release for up to 7 days). Pumps containing 50\% DMSO in sterile saline were used as controls. At 7 days after morphine and/or naltrexone, or control implantation, animals were euthanatized by perfusion with Zamboni's fixative (4\% paraformaldehyde, pH 7.4 supplemented with $0.15 \%$ picric acid). Brains were removed, cryopreserved by serial exposure to 10 and $20 \%$ sucrose, embedded in Tissue Tek optimal cutting temperature compound (Sakura Finetek, Torrance, CA), and stored at $-80^{\circ} \mathrm{C}$.

\section{Enzyme-Linked Immunosorbent Assay}

At 48 hours after treatment, mice were euthanized and brain samples were placed in $2 \mathrm{ml}$ of PBS with protease inhibitors (Roche Diagnostics). An extract of striatum was prepared by homogenization using a Precellys $24 \mathrm{Ho}$ mogenizer (MO BIO Laboratories, Inc., Carlsbad, CA; $3 \times 10$ seconds). The homogenate was centrifuged at $12,000 \mathrm{rpm}$ for 10 minutes at $4^{\circ} \mathrm{C}$, after which the supernatants were collected, aliquoted, and frozen at $-80^{\circ} \mathrm{C}$ until cytokine assays were performed. IL-6, CCL2/MCP-1 and CCL5/RANTES were measured in brain homoge- 
Table 1. Sequences of Quantitative Real-Time PCR and RT-PCR Primers

\begin{tabular}{|c|c|c|}
\hline Gene & Forward RT-PCR primer & Reverse RT-PCR primer \\
\hline $\begin{array}{l}\beta \text {-Actin } \\
\text { CCL5/ RANTES } \\
\text { CCL2/ MCP-1 } \\
\text { IL-6 }\end{array}$ & $\begin{array}{l}\text { 5'-TGTGATGGTGGGAATGGGTCAG-3' } \\
\text { 5'-CAGCTGCCCTCACCATCATCCTCA-3' } \\
\text { 5'-GGGTCTTTGGGAATATAATGTGTA-3' } \\
\text { 5'-TGGAAATTGGGGTAGGAAGGA-3' }\end{array}$ & $\begin{array}{l}\text { 5'-TTTGAGTGTCACGCACGATTTCC-3' } \\
\text { 5'-GCTGGTTTCTTGGGTTTGCTGTGC-3' } \\
\text { 5'-AGCCCTGTGCCTCTTCTTCT-3' } \\
\text { 5'-GTTGCCTTCTTGGGACTGATG-3' }\end{array}$ \\
\hline Gene & Forward quantitative real-time PCR primer & Reverse quantitative real-time PCR primer \\
\hline $\begin{array}{l}\beta \text {-Actin } \\
\text { DOPr } \\
\text { MOPr } \\
\text { KOPr } \\
\text { PDYN } \\
\text { PENK } \\
\text { POMC }\end{array}$ & $\begin{array}{l}\text { 5'-CGTGAAAAGATGACCCAGATCATG-3' } \\
\text { 5'-AGTGACCCAACCCCGGGATGGT-3' } \\
\text { 5'-CATGGCCCTCTATTCTATCGTGT-3' } \\
\text { 5'-GCATCAGGAACGTGGACCCATCA-3' } \\
\text { 5'-CGTCCCATCAACCCCCTGATTT-3' } \\
\text { 5'-CGCGGTTCCTGAGGCTTTGCA-3' } \\
\text { 5'-CTGTTGCTGGCCCTCCTGCTTCA-3' }\end{array}$ & $\begin{array}{l}\text { 5'-CGTCTCCGGAGTCCATCACAA-3' } \\
\text { 5'-CTGCGCAGGCGCAGTAGCATGA-3' } \\
\text { 5'-CAGCGTGCTAGTGGCTAAGG-3' } \\
\text { 5'-TGGTATTTGTGGGGGCTTA-3' } \\
\text { 5'-CCTTGCCACGGAGCCCAGAGA-3' } \\
\text { 5'-ATTCCAGTGTGCACGCCAGGAAA-3' } \\
\text { 5'-CCCGGATGCAAGCCAGCAGGTT-3' }\end{array}$ \\
\hline
\end{tabular}

nates using Quantikine ELISA kits (R\&D Systems, Minneapolis, MN).

\section{Immunohistochemistry for Tat}

Seven different primary anti-HIV-1 Tat antibodies were tested for their utility in detecting Tat on frozen sections, including mouse monoclonal ANT0059 (Diatheva, Fano, Italy), mouse monoclonals ab42359 and ab24778 (Abcam, Cambridge, MA), chicken polyclonal ab5721 (Abcam), chicken polyclonal XW-7254 (ProSci Inc., Poway, CA), rabbit polyclonal ab43014 (Abcam), and rabbit polyclonal ANT0000 (Diatheva). The most consistent immunostaining was obtained with ab24778, and all further immunostaining was done using that antibody. Ten-micron thick sections from Tat $(-)^{\mathrm{DOX}}$ mice and Tat $(+)^{\mathrm{DOX}}$ mice were rehydrated in PBS buffer and incubated at room temperature for 30 minutes in blocking solution (1\% goat serum and 1\% Triton-X in PBS). Sections were incubated with primary antibody $(1: 100)$ at $4^{\circ} \mathrm{C}$ overnight, rinsed and incubated at room temperature in goat-antimouse-IgG-Alexa 594 (Vector Laboratories, Burlingame, CA; 2 hours) and exposed to Hoechst 33342 (5 minutes) to visualize cell nuclei. Some sections were doublestained for GFAP to assess co-localization of Tat immunostaining with astroglial cells. In those cases, a primary rabbit antibody to GFAP (1:500, Chemicon, Temecula, CA) was applied simultaneously with the primary Tat antibody, and visualization was with goat-anti-rabbit Alexa Fluor 488 (1:5000). To determine whether signals for Tat and GFAP were co-localized, digital, z-stacked images were taken at the same settings in both Tat $(+)^{\text {DOX }}$ and Tat $(-)^{\mathrm{DOX}}$ tissue through the entire thickness of the section, after which the images were processed using deconvolution software (AutoQuant X, version X2.2.0; Media Cybernetics, Bethesda, MD).

\section{RNA Extraction and Quantitative Real-Time PCR}

Mice were humanely euthanatized by cervical dislocation. The cortex, striatum and hippocampus were rapidly dissected, frozen in liquid nitrogen and stored at $-80^{\circ} \mathrm{C}$. Total RNA was isolated using TRIzol reagent (Invitrogen). Total
RNA samples were treated with RNase-free DNase I, then reverse transcribed using the High Capacity cDNA Reverse Transcription Kit (Applied Biosystems, Foster City, CA).

A quantitative real-time PCR assay for Tat expression was conducted in a Corbett Rotor-Gene 6000 real time PCR system (Quiagen, Valencia, CA). A total volume of $25 \mu$ per PCR reaction was prepared using SYBR GreenER qPCR Supermix (Invitrogen). PCR conditions consisted of an initial hold at $50^{\circ} \mathrm{C}$ for 2 minutes and then at $95^{\circ} \mathrm{C}$ for 10 minutes, followed by 40 amplification cycles of $95^{\circ} \mathrm{C}$ for $5 \mathrm{~s}, 55^{\circ} \mathrm{C}$ for $10 \mathrm{~s}, 72^{\circ} \mathrm{C}$ for $20 \mathrm{~s}$. Real-time data were collected during the extension step of each cycle. Melting curve analyses were performed at the end of the reaction between $62^{\circ} \mathrm{C}$ and $95^{\circ} \mathrm{C}$ to assess the quality of final PCR products. The primers used (Table 1) were designed to span junctions of exons and introns to avoid amplification of contaminated DNA. The PCR products amplified by all primer pairs were validated by the appearance of a single PCR product on a $1.5 \%$ agarose gel using ethidium bromide staining. Quantitation of mRNA expression was based on the comparative Ct $\left(2^{-\Delta \Delta C t}\right)$ method. ${ }^{31}$ Relative expression of the target gene was normalized to expression of an endogenous reference gene ( $\beta$-actin). At least three independent quantitative real-time PCR experiments were performed for each sample. Fold changes were analyzed using the least square differences analysis of variance (analysis of variance) and results are presented as means \pm SEM.

Chemokine/cytokine mRNA levels were assessed by semiquantitative RT-PCR. Total RNA was reversed transcribed as described and amplified using appropriate primers (Table 1). Products were separated by electrophoresis using a 1.5\% agarose gel, stained with ethidium bromide, visualized under UV light, and quantified using a Kodak 440CF Image Station (Rochester, NY). $\beta$-actin mRNA was used as an internal loading standard.

\section{Immunoprecipitation and Western Blot}

Whole brains from Tat $(+)^{\mathrm{DOx}}$, Tat $(-)^{\mathrm{Dox}}$, and Tat $(+)$ mice were homogenized in radioimmunoprecipitation assay (RIPA) buffer with protease inhibitors as described for enzyme-linked immunosorbent assy. For immunopre- 
cipitation, $12 \mu \mathrm{g}$ recombinant HIV-1 Tat ${ }_{1-86}$ (ImmunoDiagnostics, Inc., Woburn, MA) was mixed with $100 \mu$ I RIPA buffer or mouse brain tissue extracts (200 $\mu \mathrm{g}$ protein) and the mixtures were immunoprecipitated using $10 \mu \mathrm{g}$ anti-Tat antibody (ab24778) with $50 \mu$ l Dynabeads protein $\mathrm{G}$ (Invitrogen) per the manufacturer's protocol. The immunoprecipitated protein (IP) and flowthrough (FT) of input after immunoprecipitation were heated at $70^{\circ} \mathrm{C}$ for 10 minutes in SDS loading buffer, then subjected to $4 \%$ to $20 \%$ SDS-polyacrylamide gel electrophoresis (Pierce) and western blotting using anti-Tat antibody and appropriate secondary antibody conjugated with horseradish peroxidase (1:2000, Pierce, Rockford, IL). The membranes were detected using SuperSignal West Femto Maximum Sensitivity Substrate (Pierce), and visualized using a Kodak Image Station 440. Antibodies ab24778, ab42359, and ANT0059 gave equivalent results. In additional experiments, western blotting without prior immunoprecipitation was performed to determine whether Tat detection was consistent among transgenic mice. In those experiments, samples were further cleared by $10 \%$ SDS or 2-D buffer before immunoblotting as described above. Staining for $\beta$-tubulin was used as a loading control. All protein concentrations were determined by the bicinchoninic acid method using a commercial kit (Pierce).

\section{Assessment of Dendrite Pathology}

Following 7-day exposure to DOX and/or opiates, tissues were harvested and impregnated using a modified GolgiKopsch procedure that randomly labels neurons and glia. ${ }^{32}$ Briefly, mice were deeply anesthetized by halothane inhalation and euthanatized by intracardiac perfusion with $2 \%$ potassium dichromate and $5 \%$ glutaraldehyde. Perfusion fixation was conducted at room temperature, which diminishes artifactual dendritic beading. ${ }^{33}$ After perfusion, whole forebrains were isolated and immersed in $2 \%$ potassium dichromate and $5 \%$ glutaraldehyde $(\mathrm{v} / \mathrm{v})$ in the dark at room temperature. The ratio of dichromate solution to tissue volume was $\geq 50: 1$. After 5 days, tissues were rinsed in ultra-pure water three times, blotted dry between rinses, and placed in an aqueous $0.75 \%$ silver nitrate solution for 5 days in the dark (50:1 fluid to tissue volume ratio). Intact forebrains were infiltrated with graded sucrose solutions in $0.75 \%$ silver nitrate for 24 hour periods, embedded in Tissue Tek, frozen on dry ice, and stored at $-80^{\circ} \mathrm{C}$. Serial, $120-\mu \mathrm{m}$ frozen sections were cut in the coronal plane, thaw-mounted on Fisher Superfrost-Plus microscope slides, dehydrated through graded ethanols, cleared in xylene and mounted in Permount (Fisher Scientific, Waltham, MA). Nonmetallic handling devices were used in all procedures. An individual who was unaware of the treatment code quantified the slides.

We assessed both the number of dendritic spines and the morphology of dendrites on medium spiny neurons in the striatum. Each spine was then classified as having either a mature morphology, or a thin, filopodia-like shape typical of incipient or immature spines. The number of mature dendritic spines and/or filopodia were counted on three to seven third-order dendrites, recorded as the mean number of spines per $10 \mu \mathrm{m}$ dendrite length, and averaged for each animal. Changes in the mean spine density (number of spines or filopodia/10 $\mu \mathrm{m}$ ) for total spines (mature spines + filopodia) or filopodia alone were analyzed between treatment groups.

Both qualitative and quantitative assessments of dendrite morphology were also made. For purposes of quantification, 20 medium spiny neurons were randomly selected per animal (3 to 4 animals/group) and categorized as having dendrites with an entirely normal morphology, or having one or more dendrites that displayed aberrant features, such as beading and fragmentation along proximal and/or distal segments. Degenerative changes were not uniform, and many individual spiny neurons appeared to be unaffected. The proportion of neurons that possessed one or more dendrites with "beaded" varicosities was counted and reported as a percentage of total neurons examined \pm SEM.

\section{Statistical Analyses}

Morphological data were compared statistically by analysis of variance followed by Duncan's posthoc, multiple comparisons testing using Statistica 8.0 (StatSoft, Tulsa, OK). Non-parametric differences in chemokine expression were assessed using Kruskal-Wallis testing. Statistical differences in endogenous opioid peptide and receptor mRNA expression data were assessed by a least square means analysis of variance and Tukey-Kramer posthoc testing (SAS Institute, Inc., Cary, NC). An $\alpha$ level of $P \leq 0.05$ was considered significant; all data are expressed as the mean \pm SEM.

\section{Results}

\section{Detection of Tat Protein by Immunostaining and Western Blotting}

We tested seven different antibodies for their ability to specifically detect Tat protein in Tat $(+)^{\text {DOX }}$ mice. Tat $(-)^{\mathrm{DOX}}$ sections were used as negative controls. As Tat should be produced by astroglia in this transgenic mouse, Tat localization was also examined with respect to GFAP immunostaining. Most antibodies did not detect specific Tat antigeniticity. However, antibody ab24778, which also detected Tat on western blots, produced a consistent, strong signal in Tat $(+)^{\mathrm{DOX}}$ tissues. Tat immunostaining was particularly co-localized in areas where GFAP staining was abundant. Signal was found both within $\mathrm{GFAP}^{+}$cells and/or in surrounding tissue (Figure 1, $B$ and $C$ ), strongly inferring an exclusive astroglial origin. By contrast, signal was not observed in Tat $(-)^{\mathrm{DOX}}$ tissues (Figure 1A). Z-stacked images taken through the thickness of the tissue and examined after de-convolution, showed definitive localization of fluorescent Tat immunostaining within individual astroglia (Figure 1, B and C). There was also considerable signal that appeared to be extracellular. This dual localization, both in and around $\mathrm{GFAP}^{+}$cells, is predicted since it is likely that either 

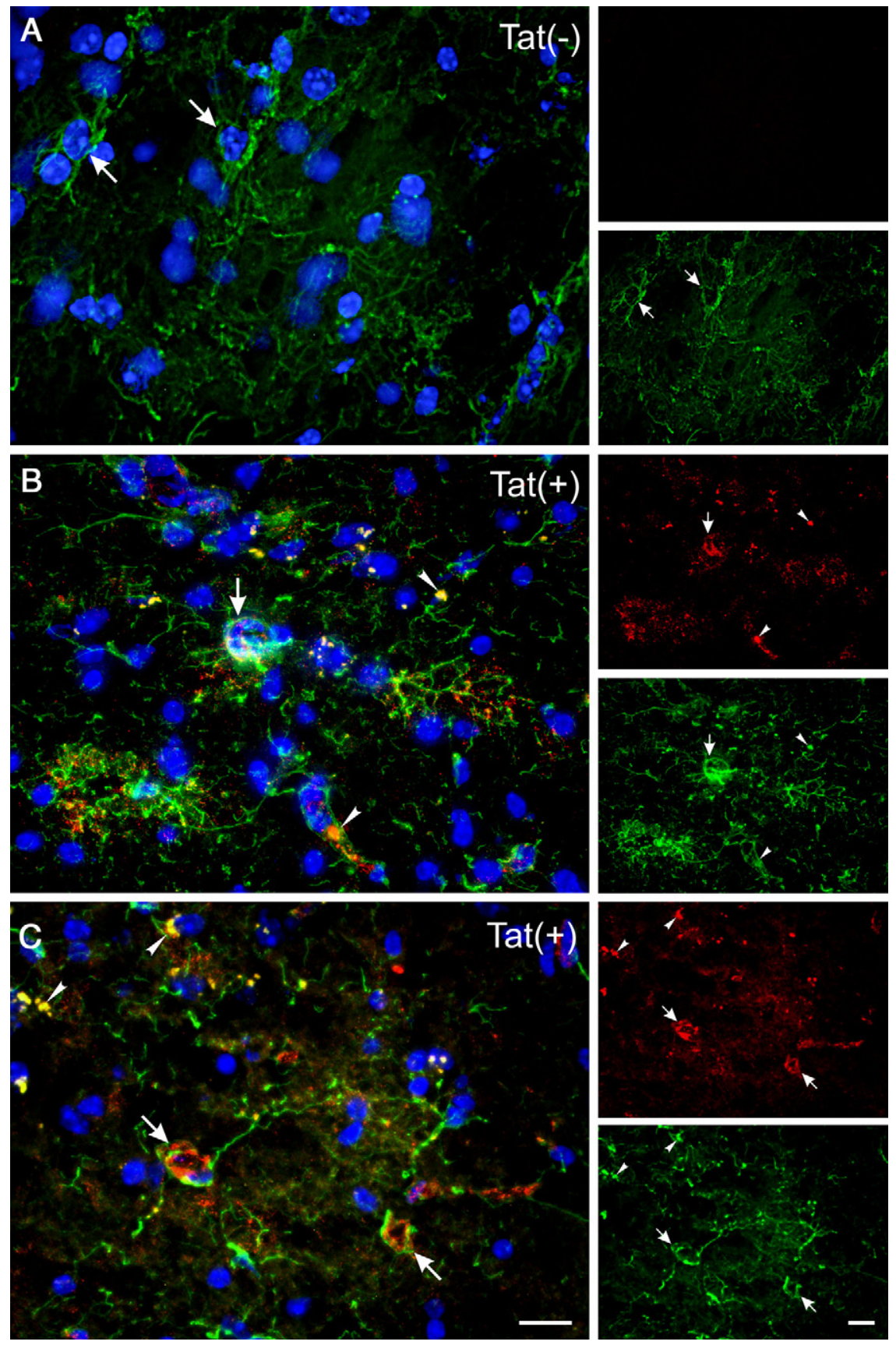

Figure 1. Immunohistochemistry for HIV-1 Tat $_{1-86}$ in $10 \mu \mathrm{m}$ sections from Tat $(-)^{\mathrm{DOX}}$ and Tat $(+)^{\text {DOX }}$ mouse striatum using anti-Tat antibody ab24778. Doxycycline was administered for ten days before perfusion. The three-color images were created from multiple z-slices taken through the thickness of the section, then deconvolved and projected onto a single plane. Panels labeled (A-C) show localization of Tat (red) in comparison with GFAP (green), with Hoechst staining (blue) of nuclei. In the smaller images to the right of each labeled panel the individual red and green channels are presented separately. Panel (A) shows that there is abundant GFAP signal in tissue from Tat $(-)^{\mathrm{DOX}}$ mice, but that Tat immunostaining is completely absent. In comparison, panels (B and $\mathbf{C}$ ) show abundant immunostaining for $\mathrm{Tat}_{1-86}$ in tissue from a Tat $(+)^{\mathrm{DOX}}$ mouse. Large arrows in panels (A-C) denote astroglial cell bodies. In (B) and (C) the astroglial cell bodies are associated with Tat immunostaining. Note that the Tat and GFAP signals are completely colocalized in certain areas (arrowheads in B and C), although in most cases the signals are proximate to one another. This pattern is predicted since Tat and GFAP signals are located in different subcellular compartments. GFAP comprises intermediate filaments while Tat may be cytoplasmic, nuclear, or secreted. All panels are presented at the same magnification, and were taken at the same exposure settings. Panels (B and $\mathbf{C}$ ) are taken from the posterior amygdala (B) and striatum (C) of a single Tat $(+)^{\mathrm{DOX}}$ mouse to emphasize that Tat is present throughout the brain. Scale bars $=15 \mu \mathrm{m}$
Tat $_{1-86}$ or fragments thereof are released from cells. It was expected that a substantial portion of Tat and GFAP signals would not co-localize, because Tat and GFAP are predicted to be located in different subcellular compartments. While GFAP is associated with intermediate filaments, Tat can be cytoplasmic, nuclear, and also secreted. Tat staining was apparent in all brain regions (two are shown in Figure 1, B and C), as expected with a transgene driven by an astrocyte promoter.

Tat $_{1-86}$ was also detected by western blotting. In initial experiments, three different anti-Tat antibodies detected a strong band at approximately $22 \mathrm{kDa}$ in blots of $\operatorname{Tat}(+)^{\mathrm{DOX}}$ whole brain lysates (Figure $2 \mathrm{~A}$, lanes $1-3$ ), although the molecular weight of $\mathrm{Tat}_{1-86}$ is predicted to be $\sim 11 \mathrm{kD}$. There was no Tat detection in lysates from Tat $(-)^{\mathrm{DOX}}$ mice, but a faint band was detected in the Tat(+) mice that did not receive DOX treatment, suggesting that the promoter is constitutively active at a low level (Figure 2A, lanes 4,5). Since Tat reportedly has a strong tendency both in vivo and in vitro to form stable multimers that are resistant to reducing and/or denaturing conditions, ${ }^{34-37}$ we examined whether this was occurring in our preparations. Western blotting of IP from a solution of recombinant Tat $_{1-86}$ showed strong bands at $\sim 23 \mathrm{kDa}$ and $50 \mathrm{kDa}$, roughly the predicted weight of dimeric and tetrameric forms of $\mathrm{Tat}_{1-86}$ (Figure 2B, lane 1). A fainter band was detected at the predicted weight of the monomer. In contrast, recovery of the monomer form appeared 
A

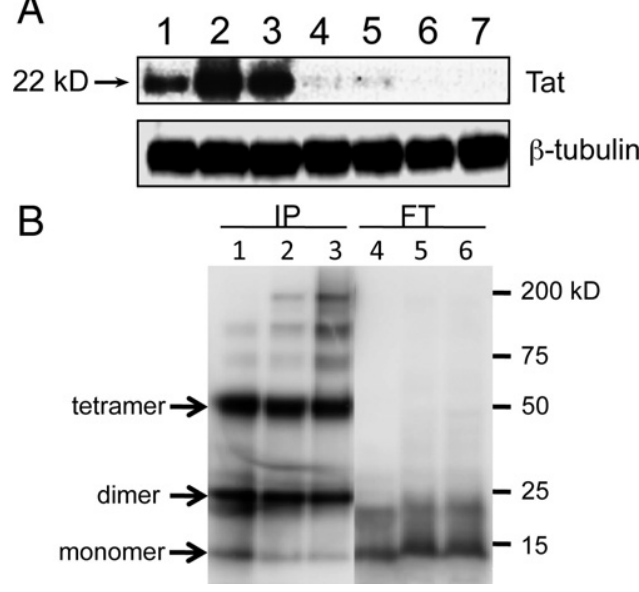

Figure 2. Detection of HIV-1 Tat ${ }_{1-86}$ protein by western blot before and after immunoprecipitation. Panel (A) shows the results of western blots with anti-Tat antibody ab24778 on whole brain lysates from Tat $(+)^{\mathrm{DOX}}$ mice (lanes 1-3), Tat $(+)$ mice that did not receive DOX (lanes 4-5) and Tat $(-)$ mice (lanes 6-7). Each lane represents lysate from a different mouse. For each Tat $(+)^{\mathrm{DOX}}$ mouse a relatively strong band is detected by this antibody at $\sim 22 \mathrm{kDa}$ (lanes 1-3). There is a very faint band at the same molecular weight in Tat $(+)$ mice even without DOX induction (lanes $\mathbf{4}$ and 5), suggesting constitutive ("leaky") promoter activity that results in tonic, low levels of Tat production. We did not detect a signal at any molecular weight in blots of lysate from Tat $(-)$ mice, even with long term exposure of the blots. Panel (B) shows the results of studies to determine the propensity of HIV-1 Tat ${ }_{1-86}$ to form oligomers. Twelve micrograms of recombinant HIV-1 Tat ${ }_{1-86}$ (ImmunoDiagnostics, Inc.) was mixed with RIPA buffer alone, or with $200 \mu \mathrm{g}$ protein mouse brain tissue extracts in RIPA buffer, and the mixtures were subjected to immunoprecipitation using anti-Tat antibody (ab24778). Numbered lanes show the results of western blotting for the IP (lanes 1-3) and FT (lanes 2-4) for corresponding samples. Lanes 1 \& 4, IP and FT of Tat ${ }_{1-86}$ mixed with RIPA buffer only; Lanes $\mathbf{2}$ and 5, IP and FT of Tat $_{1-86}$ mixed with brain tissue extract of Tat $(-)$ mouse; Lanes $\mathbf{3}$ and $\mathbf{6}$, IP and FT of Tat ${ }_{1-86}$ mixed with brain tissue extract of Tat $(+)$ transgenic mouse induced with doxycycline. Arrows indicate Tat monomer, dimer and tetramer bands, as labeled. A comparison of the corresponding IP and FT lanes for different samples suggests efficient immunoprecipitation of Tat multimers, but not Tat monomers. Recovery of the dimeric and tetrameric forms of Tat is noticeably greater in all IP lanes than recovery of monomers; conversely, recovery of monomers is greater in FT lanes. This is true even in lanes $\mathbf{1}$ and $\mathbf{4}$, which were loaded with buffer + recombinant Tat and did not contain tissue samples, suggesting the tendency of HIV-1 Tat to oligomerize, as noted by others. ${ }^{34-37}$

to be greater in the FT lane (Figure 2B, lane 4). The same pattern of greater recovery of multimeric forms of Tat was observed in immunoprecipitate from samples containing both recombinant Tat and tissue (Figure 2B, lanes 2-3, 5-6). Considering both IP and FT lanes, the overall density of the dimer and tetramer bands was far greater than that of the monomer bands. The results of the immunoprecipitation study strongly suggest the preferential tendency of HIV-1 Tat $_{1-86}$ to form multimers under our conditions. They also suggest that these Tat antibodies may preferentially bind Tat multimers. Overall, the western blot studies show that Tat can be detected in the brains of Tat $_{1-86}$ transgenic mice, and that while there is probably a low level of constitutive promoter activity, DOX tremendously enhances Tat expression.

\section{Opiates and/or HIV-1 Tat Cause Increased Expression of Pro-Inflammatory \\ Chemokine/Cytokines}

Homogenates of Tat $(-)^{\mathrm{DOX}}$, Tat $(+)$, and Tat $(+)^{\mathrm{DOX}}$ striatum were detected by ELISA after 48 hours of DOX treat-
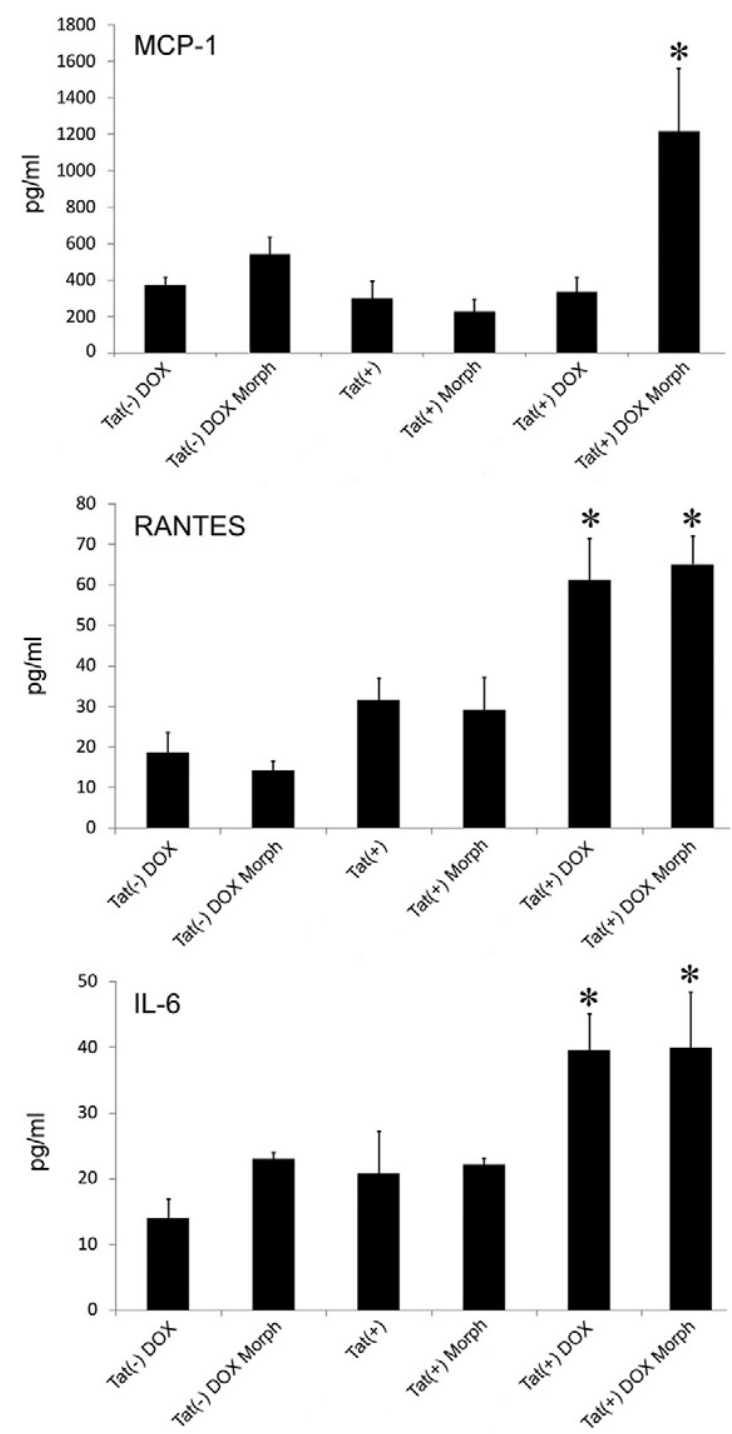

Figure 3. Effects of morphine exposure and Tat-induction with doxycycline (DOX) for 48 hours on (A) CCL2/MCP-1, (B) CCL5/RANTES, and (C) IL-6 in striatum as measured by ELISA. Significant effects of morphine and/or DOX treatment were not seen in Tat $(-)$ mice. In the Tat transgenic $[$ Tat $(+)]$ mice, while neither Tat induction [Tat(+) DOX] nor morphine treatment (Morph) alone enhanced CCL2/MCP-1 levels, the combination caused a synergistic increase [Tat $(+)$ DOX Morph]. In the case of both CCL5/RANTES and IL-6, Tat induction [Tat $(+)$ DOX] significantly elevated tissue levels, while co-exposure to morphine [Tat $(+)$ DOX Morph] had no synergistic effect. ( $n=5$ mice per group; ${ }^{*} P<0.05$; analysis of variance and Duncan's post hoc test versus all unmarked groups).

ment. As shown in Figure 3, HIV-1 Tat induction by DOX and/or co-exposure to morphine, significantly enhanced expression of CCL5/RANTES, IL-6, and CCL2/MCP-1 within the striatum. Significant effects of morphine and/or DOX treatment were not seen on any of the analytes in Tat $(-)$ mice. Both CCL5/RANTES and IL-6 were elevated in Tat $(+)^{\mathrm{DOX}}$ mice as compared with Tat $(-)^{\mathrm{DOX}}$ controls, while co-exposure to morphine had no synergistic effect. In contrast, although CCL2/MCP-1 protein levels were not increased in Tat $(+)$ mice by DOX induction alone, the combination of DOX and morphine caused a synergistic increase ( $n=5$ mice per group). Results suggest that exposure to Tat or Tat and morphine significantly en- 
Table 2. Summary of Results

\begin{tabular}{|c|c|c|c|c|c|c|c|c|}
\hline \multicolumn{8}{|c|}{$\begin{array}{l}\text { Tat-induced changes in the endogenous opioid system: comparison of } 3 \text { brain } \\
\text { regions }\end{array}$} & \multirow{9}{*}{ Plasticity } \\
\hline & \multicolumn{2}{|c|}{ Striatum } & \multicolumn{3}{|c|}{ Cortex } & \multicolumn{2}{|c|}{ Hippocampus } & \\
\hline mRNA & Tat(+) & Tat(+) $)^{\mathrm{DOX}}$ & Tat( & & Tat(+) ${ }^{\mathrm{DOX}}$ & Tat(+) & Tat(+) ${ }^{\mathrm{DOX}}$ & \\
\hline MOP-r & n.s. & n.s. & $\uparrow$ & & $\downarrow$ & n.s. & $\downarrow$ & \\
\hline DOP-r & n.s. & n.s. & n.s & & n.s. & n.s. & n.s. & \\
\hline KOP-r & $\downarrow$ & $\uparrow$ & $\uparrow$ & & $\uparrow$ & n.s. & n.s. & \\
\hline POMC & n.s. & $\downarrow$ & n.s & & n.s. & n.s. & n.s. & \\
\hline PENK & $\downarrow$ & n.s. & n.s & & n.s. & $\downarrow$ & $\downarrow$ & \\
\hline PDYN & n.s. & $\downarrow$ & $\uparrow$ & & n.s. & $\uparrow$ & $\downarrow$ & \\
\hline \multicolumn{8}{|c|}{ Tat and/or morphine-induced changes in tissue from striatum ${ }^{\dagger}$} & \\
\hline \multirow{4}{*}{\multicolumn{2}{|c|}{ Inflammation }} & & & Tat(+) & Tat(+) $)^{\text {DOX }}$ & Morphine & $\begin{array}{l}\text { Tat/morphine } \\
\text { synergy? }\end{array}$ & \\
\hline & & MCP-1 & & n.s. & n.s. & n.s. & Yes $(\uparrow)$ & \\
\hline & & RANTES & & n.s. & $\uparrow$ & n.s. & No & \\
\hline & & IL-6 & & n.s. & $\uparrow$ & n.s. & No & \\
\hline \multirow{2}{*}{\multicolumn{2}{|c|}{ Spine plasticity }} & Spine density & & n.s. & $\downarrow$ & $\downarrow$ & No & \\
\hline & & Filopodia dens & & n.s. & n.s. & n.s. & No & Pathology \\
\hline \multicolumn{2}{|c|}{ Dendrite pathology } & $\begin{array}{l}\text { Beading/fragm } \\
\text { in dendrites of } \\
\text { neurons }\end{array}$ & $\begin{array}{l}\text { ation } \\
\text { רy }\end{array}$ & $\uparrow$ & $\uparrow$ & n.s. & Yes $(\uparrow)$ & \\
\hline
\end{tabular}

NS, not significant.

$\operatorname{Tat}(+)=$ Tat transgenic; Tat $(+)^{\mathrm{DOX}}=$ Tat transgenic, induced with doxycycline

${ }^{*} \uparrow$ or $\downarrow$ indicate significant increases or decreases in endogenous opioid receptors or peptides compared to levels in Tat(-) $)^{\text {Dox }}$ tissue from the same region.

$\uparrow \uparrow$ or $\downarrow$ indicate significant increases or decreases in chemokines/cytokine levels, spine plasticity, and dendrite pathology compared to Tat(-) $)^{\mathrm{DOX}}$ controls. MOP-r, DOP-r, and KOP-r, respectively, refer to $\mu, \delta$, and $\kappa$ opioid receptors; POMC, PENK, and PDYN, respectively, refer to the proopiomelanocortin, proenkephalin, and prodynorphin endogenous opioid peptide mRNAs.

hance the accumulation of inflammatory chemokines and cytokines in the striatum, and that the responses to Tat and morphine are specific to individual analytes. These results are summarized in Table 2.

\section{Morphine and/or Tat-Induced Reduction in Dendritic Spines}

Effects of the Tat transgene \pm morphine on dendritic spine density (spines/10 $\mu \mathrm{m}$ dendrite) were assessed in Golgi-Kopsch impregnated medium spiny neurons (Figure 4A). Total spine density, not taking into account morphological subtypes, was unaffected by low levels of Tat expression from the leaky promoter, but was significantly decreased in Tat $(+)$ mice induced with DOX $[P<0.05$ vs both Tat $(-)$ and uninduced Tat $(+)$ ]. Chronic treatment with morphine alone significantly reduced total spine density in both Tat $(-)$ and Tat $(+)$ mice $(P<0.05)$, and this was reversed by naltrexone $(P<0.05)$. There was no interactive effect of Tat and morphine on total spine density. We also examined Tat and morphine effects on the subtype of dendritic spines with a filopodial morphology. These represent a more immature stage of development, and may reflect spines undergoing dynamic restructuring. Interestingly, the only treatment that produced a significant change in the density of filopodia was naltrexone administration, and this only occurred in Tat $(+)^{\mathrm{DOX}}$ mice receiving morphine. In this group, the overall spine density was similar to all other groups, but the proportion of filopodia was increased (Figure 4B).

\section{Morphine and/or Tat-Induced Changes in Dendrite Structure}

Effects of the Tat transgene \pm morphine on dendrite morphology were assessed in Golgi-Kopsch impregnated medium spiny neurons. Normal axon and dendrite morphology in spiny neurons is shown and described in Figure 5, A-C, while pathological changes are depicted and quantified in Figures 6, A-Y and 7, and Table 2. Morphine exposure and Tat induction have differential effects. Qualitatively, Tat(-) mice showed normal dendritic morphology (Figure 6, A-D) on proximal (Figure 6C) and distal (third order; Figure 6D) segments of spiny neuron dendrites. In Tat $(+)$ mice that did not receive DOX, about $25 \%$ of neurons had dendrites with aberrant pathophysiological features (beading and fragmentation) along proximal and distal segments (Figure 7). Chronic Tat induction by DOX (7 days; Figure 6, I-Q) did not enhance the degenerative changes. The distal segments of affected spiny neurons had a transitional morphology, with dendrites that were denuded of spines and exhibiting at least partial beading (Figure $6, \mathrm{~N}, \mathrm{O}$, and $\mathrm{Q}$ ). Degenerative changes were not uniform among individual neurons, with some appearing quite normal. The combination of chronic morphine exposure and Tat induction by DOX caused defects in dendrite morphology that were qualitatively worse than with either treatment alone (Figure $6, R-Y)$, including severe beading and degeneration in almost $50 \%$ of neurons (Figures $6 \mathrm{~W} ; 7$ ). Even in cases of 


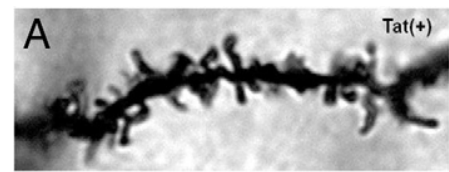

B
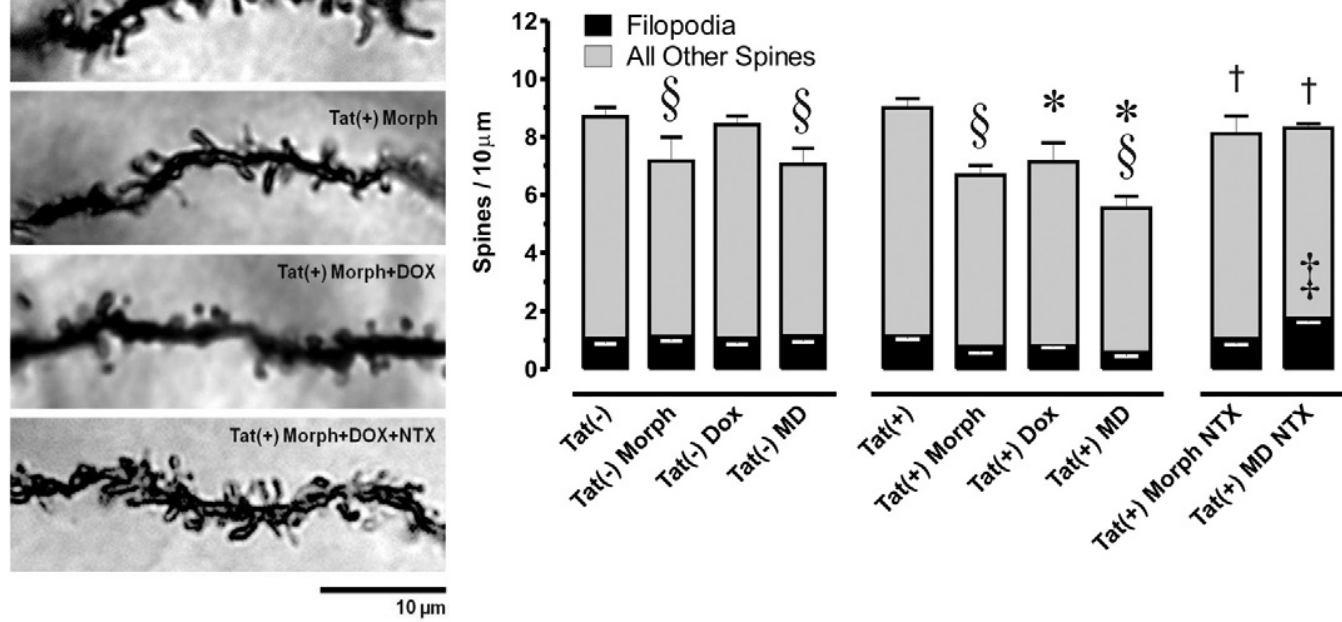

Figure 4. A: Effects of chronic opioid exposure and/or HIV-1 Tat transgene expression on dendritic spine density in striatal spiny neurons. Spine density was assessed in Golgi-Kopsch impregnated neurons after seven days of morphine treatment and/or Tat induction. B: Note that filopodia (incipient spines) were considered independently (black bars) as a subset of the total spines (black bars + gray bars). Significant decreases in total spine density were seen in the Tat + mice following induction with doxycycline $\left[\operatorname{Tat}(+)\right.$ Dox] compared with un-induced Tat $(+)$ or wild-type Tat $(-)$ mice $\left({ }^{*} P<0.05\right)$, while the density of dendritic spines was unaffected by the Tat transgene alone $[$ Tat $(+)]$. Chronic morphine treatment (Morph) significantly reduced the number of total spines in both Tat $(-)$ and Tat $(+)$ mice $\left({ }^{\$} P<0.05\right)$, while the morphine-dependent spine losses in Tat $(+)$ mice \pm DOX were antagonized by co-administering naltrexone (NTX) $\left({ }^{\dagger} P<0.05\right)$. Lastly, NTX alone caused increased numbers of filopodia per unit length, but only in Tat $(+)$ DOX mice $\left({ }^{\ddagger} P<0.05\right.$ vs. all of the other groups; filopodia only); combined morphine exposure plus Tat $(+)$ induction with DOX = MD. Significance was assessed by analysis of variance with posthoc Duncan's test.

severe dendritic pathology, axons were easily distinguished from dendrites. Interestingly, co-exposure to morphine did not enhance dendritic pathology in the uninduced Tat $(+)$ mice. Morphine effects were specific to opioid receptor stimulation since they were reversed by naltrexone.

\section{HIV-1 Tat Regulates Expression of Opioid Peptides and Receptors}

Quantitative real-time PCR analyses were conducted to examine expression of mRNAs for $\mu, \delta$, and $\kappa$ opioid receptors (MOPr, DOPr, and $\mathrm{KOPr}$, respectively), as well as the endogenous opioid peptide precursors proenkephalin (PENK), prodynorphin (PDYN), and proopiomel- anocortin (POMC). The relative expression levels of these genes in brain tissue taken from wild-type Tat $(-)$, Tat $(+)$, and $\operatorname{Tat}(+)^{\mathrm{DOX}}$ mice are shown in Figure $8, \mathrm{~A}-\mathrm{F}$ and additionally summarized in Table 2. When cDNA from whole brain was used as a template, there were no significant differences between groups of mice, except for increased KOPr mRNA in Tat $(+)^{\mathrm{DOX}}$ mice (Figure $8 \mathrm{C}$ ). However, when mRNAs from individual CNS regions were examined, several differences between the groups were apparent. In the cerebral cortex, mRNAs for MOPr, KOPr, and PDYN were significantly increased in Tat $(+)$ as compared with Tat $(-)$ mice, even without Tat induction by DOX. This likely results from constitutive promoter activity, and represents a response to chronic, low levels
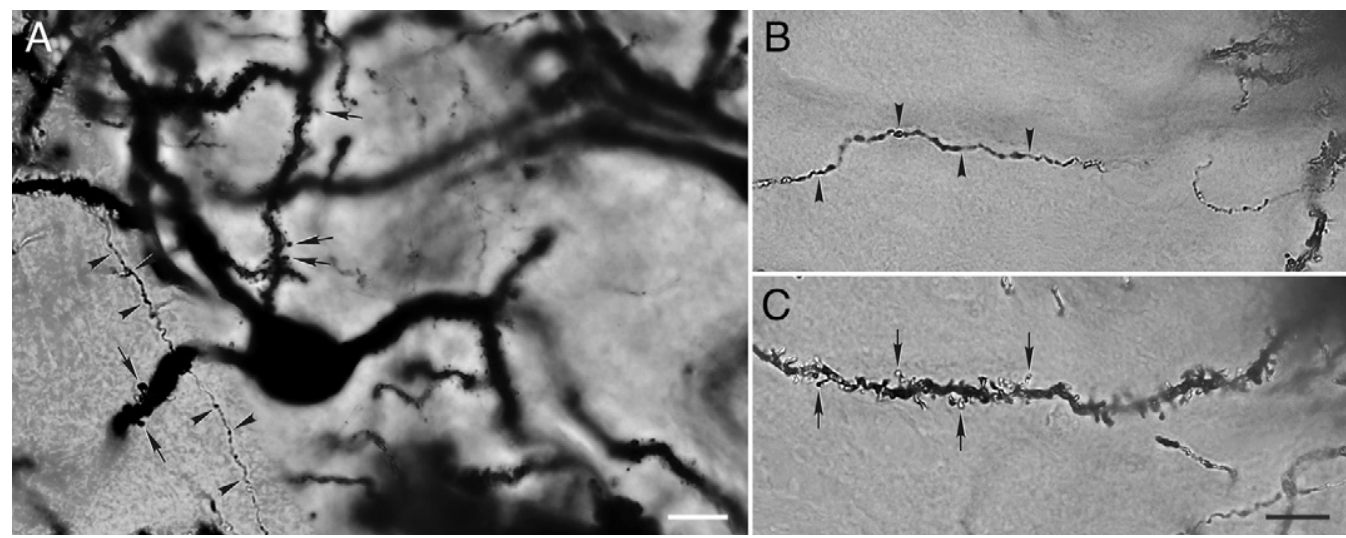

Figure 5. Golgi-Kopsch impregnated striatal spiny neurons from Tat $(-)$ mice $(\mathbf{A}-\mathbf{C})$ illustrate the morphology of normal spiny neurons. The image in $(\mathbf{A})$ is a montage, created to show both axons and dendrites which were originally in different planes of focus. The dendrites/cell body and axon were projected from multiple z-slices $(0.24 \mu \mathrm{m}$ each) using a deconvolution program (AutoQuant X, version X2.2.0). Note that the axons (arrowheads) (A, B) are much smaller in diameter than dendrites (arrows) (A, C), rarely branch, and maintain a uniform diameter after branching. In contrast, dendrites are much greater in diameter, typically branch at acute angles, and display prominent spines; $\mathbf{B}$ and $\mathbf{C}$ are the same field shown at different levels of focus; scale bars $=10 \mu \mathrm{m}(\mathbf{A})$ and $15 \mu \mathrm{m}$ (C). (B) is the same magnification as $(\mathbf{C})$. 

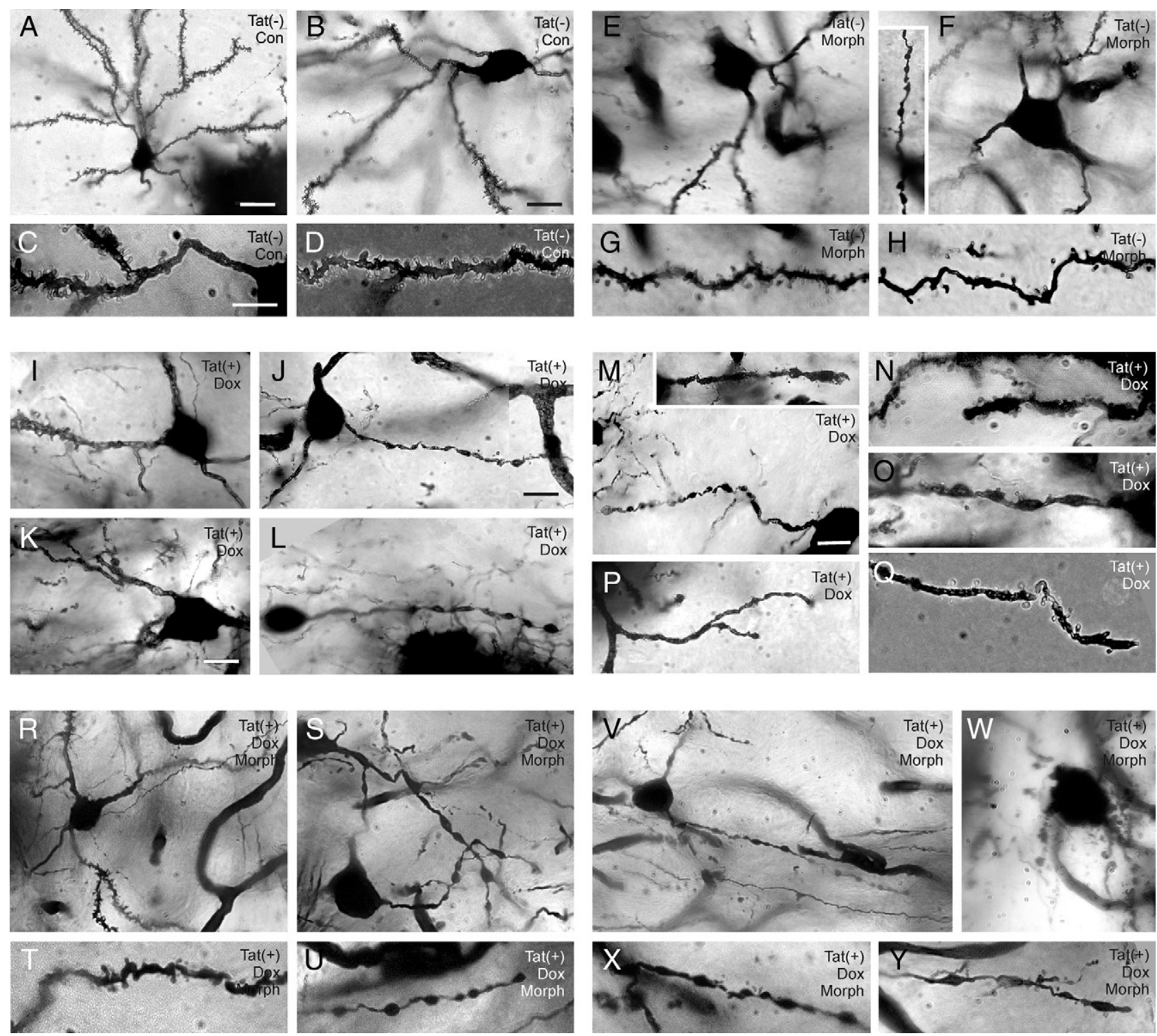

Figure 6. Morphine exposure and Tat induction have differential effects on dendritic pathology. Tat(-) mice show normal dendritic morphology and spine distribution (A-D) on proximal (C) and distal (third order; D) segments of striatal neuron dendrites. Chronic morphine (Morph) exposure (seven days; E-H) reduced spine density especially along more distal dendritic segments (F inset, $\mathbf{H}$ ). By contrast, chronic Tat induction with doxycycline (Dox) (seven days; $\mathbf{I}-\mathbf{Q}$ ) caused beading along the proximal and distal segments of many striatal neurons; the degenerative changes were non-uniform among individual neurons, with some neurons appearing normal. Spine densities were markedly diminished in the distal segments of many neurons with Tat induction (J-Q), and presumed transitional forms of partially beaded dendrites $(\mathbf{M}, \mathbf{N}, \mathbf{O}, \mathbf{Q})$ that were additionally denuded of spines were evident $(\mathbf{M}$ inset, $\mathbf{N}, \mathbf{O}, \mathbf{Q})$. In combination, morphine exposure and Tat induction cause severe deficits in spine numbers and defects in dendritic morphology (R-Y), including severe beading and degeneration (W), qualitatively worse than with either treatment alone. Different z-plane images of some neurons were projected into a single 2-dimensional image using deconvolution (AutoQuant) $(\mathbf{C}-\mathbf{H}, \mathbf{T}-\mathbf{U}, \mathbf{X}-\mathbf{Y})$ or extended focusing (Extended Focus Module, AxioVision, Zeiss) (A, B, K, M, R) software as described before ${ }^{10}$; scale bars $=20 \mu \mathrm{m}(\mathbf{A})$ and $10 \mu \mathrm{m}(\mathbf{B}, \mathbf{C}, \mathbf{J}, \mathbf{K}, \mathbf{M}) ;(\mathbf{B}, \mathbf{E}, \mathbf{F}, \mathbf{I}),(\mathbf{C}-\mathbf{D}, \mathbf{G}-\mathbf{H}, \mathbf{N}, \mathbf{O}, \mathbf{Q}, \mathbf{T}, \mathbf{U}, \mathbf{W}-\mathbf{Y}),(\mathbf{K}, \mathbf{L})$ and $(\mathbf{M}, \mathbf{P}, \mathbf{R}, \mathbf{S}, \mathbf{V})$ are the same magnification

of Tat expression. KOPr mRNA levels were also enhanced, but only after DOX induction. In both the hippocampus and striatum, opiate-related mRNAs were more generally decreased. In the hippocampus, mRNA for PENK was significantly lower in un-induced Tat(+) vs. Tat $(-)$ mice, while Tat induction by DOX caused a reduction in levels of MOPr and prodynorphin mRNAs. In the striatum, KOPr and PENK were reduced in Tat $(+)$ mice, and similar effects on POMC and PDYN were observed with DOX induction. Overall, the results suggest that HIV-1 Tat exposure can regulate both opioid peptides and receptors in the CNS, and that effects are region specific. Since a relatively small proportion of neural cells express opioid receptors or peptides in any brain region, the changes measured in mRNA levels constitute much larger changes within individual cells, and are likely to underlie significant functional differences.

\section{Discussion}

\section{Detection of Tat ${ }_{1-86}$ in Transgenic Mouse Brain}

Tat protein has historically been difficult to detect in situ, and in earlier studies we validated the brain-specific 


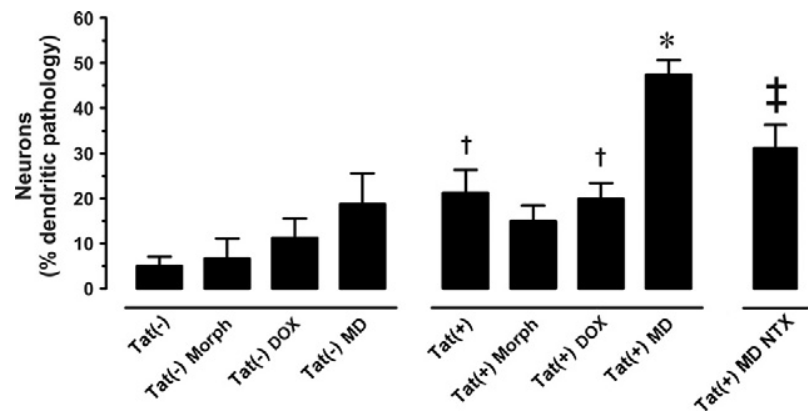

Figure 7. Effects of the Tat transgene \pm morphine on the morphology of dendrites. Neurons in un-induced Tat $(+)$ mice showed increased evidence of beading and degeneration as compared with Tat $(-)$ mice, and induction by DOX did not increase degenerative changes $\left[{ }^{\dagger} P<0.05\right.$ vs. Tat $\left.(-)\right]$. Co-exposure to morphine caused a dramatic increase in dendrite pathology in the DOX-induced Tat $(+)$ mice $\left[{ }^{*} P<0.05\right]$, but not in the Tat $(+)$ mice with basal promoter activity. Morphine effects were reversed by naltrexone (NTX) $\left[{ }^{\ddagger} P<0.05\right]$. Significance was assessed by analysis of variance with posthoc Duncan's test. Morph $=$ morphine $;$ DOX $=$ doxycycline; $\mathrm{MD}=$ morphine and DOX.

induction of Tat by DOX in these transgenic mice using PCR amplification from specific Tat primers. ${ }^{10,14,38}$ In the present study, we screened multiple anti-Tat antibodies for their ability to detect Tat by immunostaining and western blot. Although not all antibodies detected Tat, consistent fluorescent immunolabeling in Tat $(+)^{\mathrm{DOX}}$ mice was obtained using Tat ab24778 (Abcam) (Figure 1). Signal was apparent throughout the brain, as expected since the transgene is driven by a GFAP promoter. The signal intensity varied even within a given brain region, possibly due to variable proportions of astroglia or differential activation of the GFAP promoter. Multiple z-slices taken through the thickness of the section were
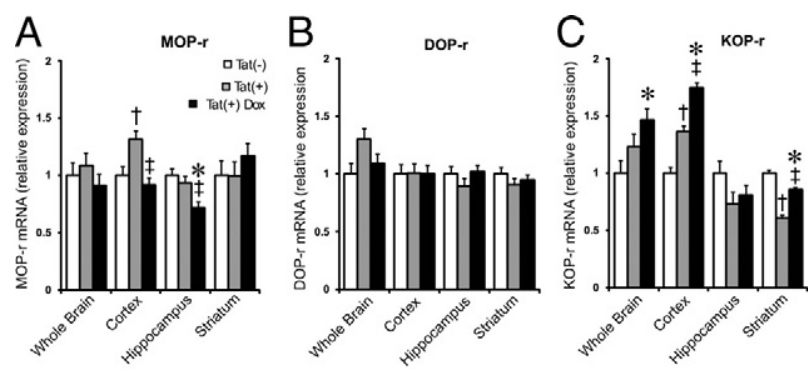

D

$\mathrm{E}$

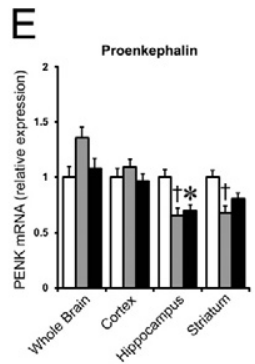

$\mathrm{F}$
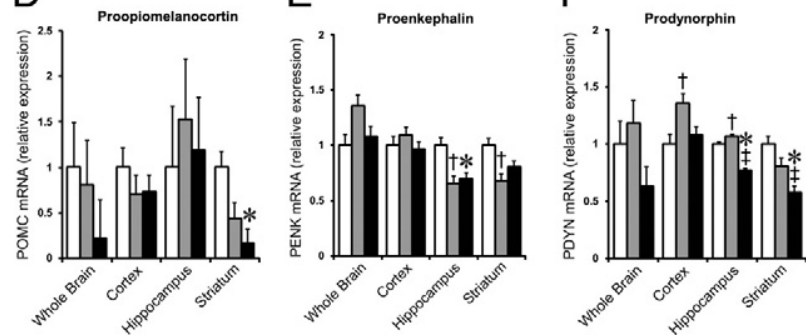

Figure 8. The effects of the HIV-1 Tat transgene on opioid receptor (A) MOP-r, (B) DOP-r, (C) KOP-r and opioid peptide precursor, (D) proopiomelanocortin (POMC), (E) proenkephalin (PENK), and (F) prodynorphin (PDYN) mRNA expression in the striatum, cerebral cortex, and hippocampus were assessed by quantitative real-time PCR at 48 hours (fold-change). The Tat transgene $[\operatorname{Tat}(+)]$ and/or Tat induction with doxycycline [Tat $(+) \operatorname{Dox}]$ caused widespread disruption to the opioid system compared with wild-type $[$ Tat $(-)]$ mice; ${ }^{*} P<0.05$, Tat $(-)$ vs. Tat $(+) \operatorname{DOX} ;{ }^{\dagger} P<0.05$, Tat $(-)$ vs. $\operatorname{Tat}(+) ;{ }^{\ddagger} P<0.05$, Tat $(+)$ vs. Tat $(+)+\operatorname{DOX}(n=6$ mice per group $)$. deconvolved and projected onto a single plane to show the relationship between Tat and GFAP. Many astroglial cell bodies in Tat $(+)^{\mathrm{DOX}}$ mice were clearly associated with abundant Tat immunostaining, either within the cell or in the area surrounding the cell (Figure 1, B and C). Tat and GFAP signals were sometimes completely co-localized. Since Tat and GFAP reside in different subcellular compartments, and Tat is also released from cells, this mixture of proximate and overlapping signals is quite reasonable. On western blots, Tat $_{1-86}$ was routinely detected as a $\sim 22 \mathrm{kDa}$ band (Figure 2A), while the predicted molecular weight is 11 $\mathrm{kDa}$. Although Tat has been reported to function as a monomer, ${ }^{39,40}$ other reports suggest a strong tendency to form stable multimers that are resistant to strong reducing and/or denaturing conditions both in vivo and in vitro, ${ }^{34-37}$ and that may be functional. ${ }^{37}$ Dimerization appears to stabilize Tat within cells, ${ }^{41}$ and the suggestion has been made that release of dimers may prevent degradation and enhance uptake by neighboring cells. ${ }^{36}$ To ascertain whether Tat formed multimers under our conditions, we performed western blots on the immunoprecipitate and flowthrough for a sample containing recombinant Tat. Strong bands were detected at $22 \mathrm{kDa}$ and $50 \mathrm{kDa}$ for the immunoprecipitate with a much fainter band at $\sim 12 \mathrm{kDa}$. Conversely, the $12 \mathrm{kDa}$ band was more pronounced in the FT blot. This pattern indicates efficient recovery of Tat dimers and tetramers, and less recovery of Tat monomers. The density of the $22 \mathrm{kDa}$ and $50 \mathrm{kDa}$ bands were, in aggregate, much stronger than those at $12 \mathrm{kDa}$, suggesting that a considerable proportion of Tat ${ }_{1-86}$ was oligomerized. Similar results were obtained for samples where recombinant Tat was added to brain tissue lysates. No additional bands were detected in those samples, illustrating that the specificity of the antibody was entirely related to Tat $_{1-86}$. Overall, we interpret the immunostaining and western blot results to show that Tat is produced in these mice in association with astroglia as expected. Further, Tat recovered from brain lysates is primarily in the form of dimers or tetramers. We cannot say whether Tat oligomers exist in the tissue, or whether oligomer formation is a function of the recovery conditions. Importantly, the constitutive promoter activity suggested by the western blots explains previously documented pathologies in Tat $(+)$ mice that were not DOX-induced, ${ }^{10,14}$ as well as changes in dendrite morphology (Figure 7) and opioid tone (Figure 8 ) reported in the present paper.

\section{Structural Changes in Dendrites Induced by HIV-1 Tat \pm Morphine}

Using this Tat transgenic mouse model, we previously found that Tat and morphine synergize in vivo to markedly increase reactive astroglia and macrophages/microglia $\left(\mathrm{F} 4 / 80^{+}\right.$or $\left.\mathrm{Mac}^{+}{ }^{+}\right)$in the striatum, even after only 2 days of co-exposure. ${ }^{14}$ Although cleaved caspase- 3 was elevated in neurons after 2 days, there was no evidence of neuron death (terminal deoxynucleotidyl transferase-me- 
diated dUTP nick-end labeling) even after 10 days of co-exposure. Since HIV-1 Tat and morphine clearly synergize to produce striatal neuron loss in culture, ${ }^{13,23}$ we hypothesized that neuron death in vivo might be delayed given the different cellular environment. In that case, we reasoned that there might be sublethal indications of neurotoxicity, and thus examined medium spiny neurons for structural alterations indicative of neuroplasticity (changes in spine density), and for evidence of frank degenerative changes (dendrite beading or fragmentation). Both our qualitative and quantitative assessments show that: a) chronic exposure to either morphine or HIV-1 Tat alone causes neuronal pathology; and, b) for certain endpoints, combined exposure causes pathology that is significantly more pronounced.

The magnitude of the response to Tat, as well as the synergy between morphine and Tat, varied depending on outcome measure. Even low levels of Tat expression from the leaky promoter caused some pathology, as evidenced by dendritic beading (Figure 7). Other abnormalities, such as changes in spine density, were not apparent until Tat(+) mice were exposed to DOX (Figure 5), suggesting that different thresholds of Tat exposure were required for different aspects of the pathology. As shown previously by others, ${ }^{42-44}$ chronic morphine treatment significantly reduced total spine density, and this occurred in both Tat $(-)$ and Tat $(+)$ mice (Figure 4). Coexposure to Tat and morphine failed to cause additional reductions in spine density. One might interpret this as a lack of morphine and Tat interaction, but alternatively, there may be a limit to the spine loss that can occur before a dendrite starts to degenerate, and both morphine and Tat induction by themselves may maximally reduce spine density. In contrast, morphine and Tat coexposure did enhance degenerative changes in dendrite structure. There was significantly more dendritic beading and fragmentation in striatal spiny neurons of Tat(+) mice exposed to both DOX and morphine, than to either DOX or morphine alone. The different responses of spines and neurites to Tat and morphine suggest that the pathways regulating their stability may be distinct. Overall, however, our findings that both spine loss and dendrite degeneration can occur with Tat \pm opiate exposure infer an enhanced potential for deficits in neural connectivity with co-exposure. This suggests a mechanism for CNS functional changes without obvious neuron loss.

Dendritic complexity underlies complex CNS function and behavior. ${ }^{45}$ Prior evidence from other models suggests that HIV and/or Tat, as well as opiates, can separately induce dendrite pathology. Dendritic pruning and selective postsynaptic damage have been reported with HIV-1 or SIV infections in the CNS. ${ }^{46-48}$ In addition to viral and cellular toxins associated with $\mathrm{HIV}^{2,49,50}$ endogenous opioids, ${ }^{32,51}$ as well as opioid drugs such as morphine and methadone, ${ }^{52-54}$ can also shrink dendrites and reduce the density of their spines. ${ }^{43,55}$ Opioid drugs also affect the plasticity of adult neurons. ${ }^{42,56}$ The finding that co-exposure to Tat and morphine can significantly enhance degenerative change would predict enhanced neurological deficits in co-exposed individuals, an obser- vation made in several studies of HIV patients who abuse opiates. $^{7,8}$

How might Tat and morphine interact to potentiate dendritic beading and degeneration? In the case of morphine, the drug's actions at MOPr converge with glutamatergic signals originating from AMPA receptors ${ }^{44}$ and MOPr-driven dynamin-dependent receptor internalization is causal in spine reduction. ${ }^{43,44}$ The beading phenomenon has been described as a manifestation of excitotoxic "dendrotoxicity," 57 and can be caused by a broad range of insults that disrupt ion homeostasis and cellular energetics by inhibiting ATP production. ${ }^{58}$ These include nerve growth factor deprivation, inflammatory cytokine exposure and glutamatergic, especially $N$-methyl-D-aspartate, receptor overactivation. ${ }^{58,59}$ Tat by itself is excitotoxic through diverse mechanisms, a number of which also promote structural and functional defects in dendrites. ${ }^{12,60}$ For example, Tat activates $N$-methyl-D-aspartate receptors, ${ }^{61}$ and interrupts ATP production and mitochondrial function. ${ }^{62}$ Mitochondrial dysfunction and loss of cellular energetics underscore a broad-range of excitotoxic insults that can be compartmentalized to dendrites, as well as to axons, and even to specific synapses. ${ }^{63,64}$ Tat also elevates platelet activating factor release, ${ }^{65}$ which can potentiate the effect of otherwise subtoxic concentrations of glutamate, resulting in localized beading and elevations in caspase-3. ${ }^{66}$ Clearly, morphine and Tat might synergize to adversely affect neurite structure through numerous pathways, and those affecting spine density may differ from those that converge to cause degeneration. In the present study, Tat \pm morphine elevated CCL2/MCP-1, CCL5/RANTES, and IL-6 in vivo after 48 hours (Figure 3). This parallels our previous findings in vitro ${ }^{24,27}$ and suggests enhanced inflammatory tone may contribute to dendrite pathology. From a therapeutic standpoint, it is important to recognize that synaptic apoptosis and focal losses in dendritic structure and function are not necessarily a prelude to death and in fact may be reversible. ${ }^{63,67-69}$

The inducible HIV-1 Tat transgenic mouse appears to be extremely relevant for examining the chronic effects of Tat in HIV-1 neuropathogenesis. The sublethal structural abnormalities observed over the time course of our studies may provide a model for earlier stages of HIV neuropathology that are accompanied by moderate neurological impairment, before the loss of neurons more typical of advanced neuroAIDS. Our Tat transgenic mice display a much less severe phenotype than a similar, but not identical, model described previously. ${ }^{70}$ In that model, a murine GFAP promoter was used to drive DOX-inducible, brain-specific Tat expression. This resulted in fulminant neuropathology, including astrocytosis, neuronal apoptosis, and neurite degeneration, as well as associated motor and cognitive disturbances, and premature death. Our mice display much less severe neuropathology without evidence of overt neuronal death even following 10 days of continuous Tat induction. ${ }^{10,14}$ They have remained on DOX chow for over 18 weeks with only modest reductions in running wheel activity or weight loss. ${ }^{38}$ The disparate levels of pathology in the two models are likely due to intrinsic differences in Tat expression and/or deg- 
radation, possibly due to (i) differing genetic backgrounds (C57 versus C3/C57); (ii) distinct GFAP promoters (murine versus human); (iii) differences in transgene integration into the host genome, including "position effects" or epigenetic consequences of surrounding host genes [See ${ }^{71}$ ]; and (iv) the relatively high Tat gene copy number in mice used in the previous study. ${ }^{70}$

\section{Chronic HIV-1 Tat Disrupts the Endogenous Opioid System}

Our results show that Tat exposure broadly impacts the endogenous opioid system. The heterogeneous response of individual receptors and peptides in our model is likely shaped by multiple influences including: (i) intrinsic differences in opioid gene expression among brain regions: ${ }^{72,73}$ (ii) regional discrepancies in the innate hostimmune response to HIV-1 Tat; and (iii) differences in GFAP expression/regulation among astrocytes driving different levels of Tat production in each brain region. The mechanisms by which Tat disrupts opioid peptide and receptor mRNA expression are likely to be multifactorial. Moreover, Tat-induced increases in inflammatory cytokines can intrinsically affect expression of opioid peptides and receptors in isolated astrocytes, ${ }^{7-76}$ leukocytes, ${ }^{77-79}$ and in macrophages/microglia. ${ }^{80,81}$ Importantly, such effects may not be restricted to Tat since gp120 and intact virions, can also alter opioid signaling through multiple mechanisms. ${ }^{82}$ Thus, the response of the opioid system to HIV-1 infection is not restricted to a particular brain region, peptide family or receptor. The opioid system appears to be highly plastic and modifiable by HIV-1 infection during the course of the disease.

The endogenous opioid system is widely expressed by CNS cells, including neurons and multiple glial types, ${ }^{83-85}$ as well as monocyte-derived macrophages including microglia. ${ }^{26,86-88}$ Altered opioid signaling has been implicated in the etiology of neuropathic pain, neurotrauma, and neuroimmune diseases including neuroAIDS, ${ }^{79,82,87,89,90}$ which prompted an exploration of the consequences of Tat exposure on the opioid system. The effects of Tat differed significantly between brain regions, and individual opioid genes were differentially sensitive to the level of Tat transgene expression ("low" constitutive levels vs. "high" levels with DOX-induction), and/or the duration of exposure to a particular level of expression (acute [48 hours] vs. chronic "constitutive"). Chronic exposure might involve adaptive responses that are absent with acute increases in exposure levels. Since a relatively small proportion of CNS cells express opioid receptors or peptides in any brain region, the observed changes in mRNA levels constitute much larger changes in individual cells, and likely have significant functional outcomes. DOPr was the only transcript unchanged in any sample. Prodynorphin gene and $\mathrm{KOPr}$ transcripts showed the most pronounced responses. Most notably, KOPr mRNA levels increased dramatically in the whole brain and cerebral cortex, while declining in the striatum. Despite findings to the contrary, it had been anticipated that PENK levels might be increased since IL- $1 \beta$ has been shown to increase PENK, ${ }^{91}$ and Tat exposure increases release of IL-1 $\beta$ by astrocytes. ${ }^{92}$ Since PENK-derived peptides can be anti-inflammatory and neuroprotective, ${ }^{93-95}$ reductions in PENK expression might be deleterious for the HIV-infected CNS.

Endogenous opioid peptides are tonically expressed in the CNS throughout ontogeny and tend to inhibit dendritic growth and spine formation. ${ }^{51,96}$ This may partially explain findings that exposure to the long-acting, MOPr, DOPr, and KOPr opioid antagonist, naltrexone, by itself increased the number of filopodia in morphine-exposed Tat $(+)^{\mathrm{DOX}}$ mice (Figure 4). ${ }^{32,44,51}$ The increased filopodial density (an indication of neuroplasticity) may reflect novel Tat-opioid interactions occurring with altered endogenous opioid tone. Components of the opioid system can also oppose one another. ${ }^{94}$ For example, chronic naltrexone may block both neurotoxic actions of morphine at $\mathrm{MOPr}$, and more protective actions via DOPr and perhaps $\mathrm{KOPr}$, thereby revealing competing endogenous opioidHIV-1 Tat interactions that are otherwise masked.

The capacity of the brain to recover from diverse insults is remarkable. Current evidence suggests that the neurocognitive impairment with HAND is partially reversible with aggressive highly active anti-retroviral therapy. Since emerging evidence suggests that dendritic beading is reversible, ${ }^{59}$ the sublethal dendritic damage caused by Tat, or to a lesser extent opioid exposure, may not inevitably lead to neuron death. However, combinations of sublethal insults, or increases in duration, probably make reversibility less likely. Considering that morphine can collapse dendritic spines and restrict AMPA receptor trafficking and function, ${ }^{44}$ and that Tat activates $\mathrm{N}$-methyl-D-aspartate receptor $1,{ }^{61}$ it is possible that morphine decreases the excitotoxic threshold at glutamatergic inputs, resulting in their vulnerability to Tat. We propose that the adaptive plasticity of the striatum to either chronic opioid abuse or HIV infection has serious consequences, and limits the ability for adaptation to a subsequent insult. Thus, cumulative dendritic pruning and synaptic culling resulting from chronic drug abuse and sustained HIV-1 infection may eventually sufficiently distort even a highly adaptive system like the brain into an irreversible, maladaptive state.

\section{References}

1. Navia BA, Rostasy K: The AIDS dementia complex: clinical and basic neuroscience with implications for novel molecular therapies. Neurotox Res 2005, 8:3-24

2. Gonzalez-Scarano F, Martin-Garcia J: The neuropathogenesis of AIDS. Nat Rev Immunol 2005, 5:69-81

3. Neuenburg JK, Brodt HR, Herndier BG, Bickel M, Bacchetti P, Price RW, Grant RM, Schlote W: HIV-related neuropathology, 1985 to 1999: rising prevalence of HIV encephalopathy in the era of highly active antiretroviral therapy. J Acquir Immune Defic Syndr 2002, 31:171-177

4. Fischer-Smith $\mathrm{T}$, Rappaport J: Evolving paradigms in the pathogenesis of HIV-1-associated dementia. Exp Rev Mol Med 2005, 7:1-26

5. Anthony IC, Bell JE: The Neuropathology of HIV/AIDS. Int Rev Psych 2008, 20:15-24

6. Ances BM, Ellis RJ: Dementia and neurocognitive disorders due to HIV-1 infection. Semin Neurol 2007, 27:86-92

7. Anthony IC, Arango JC, Stephens B, Simmonds P, Bell JE: The effects of illicit drugs on the HIV infected brain. Front Biosci 2008, 13:1294-1307 
8. Bell JE, Arango JC, Anthony IC: Neurobiology of multiple insults: hIV-1-associated brain disorders in those who use illicit drugs. J Neuroimmune Pharmacol 2006, 1:182-191

9. Hu S, Sheng WS, Lokensgard JR, Peterson PK: Morphine potentiates HIV-1 gp120-induced neuronal apoptosis. J Infect Dis 2005, 191:886-889

10. Hauser KF, Hahn YK, Adjan VV, Zou S, Buch SK, Nath A, Bruce-Keller AJ, Knapp PE: HIV-1 Tat and morphine have interactive effects on oligodendrocyte survival and morphology. Glia 2009, 57:194-206

11. Hauser KF, El-Hage N, Stiene-Martin A, Maragos WF, Nath A, Persidsky Y, Volsky DJ, Knapp PE: HIV-1 neuropathogenesis: glial mechanisms revealed through substance abuse. J Neurochem 2007, 100:567-586

12. Hauser KF, El-Hage N, Buch S, Nath A, Tyor WR, Bruce-Keller AJ, Knapp PE: Impact of opiate-HIV-1 interactions on neurotoxic signaling. J Neuroimmune Pharmacol 2006, 1:98-105

13. Gurwell JA, Nath A, Sun Q, Zhang J, Martin KM, Chen Y, Hauser KF: Synergistic neurotoxicity of opioids and human immunodeficiency virus-1 Tat protein in striatal neurons in vitro. Neuroscience 2001, 102:555-563

14. Bruce-Keller AJ, Turchan-Cholewo J, Smart EJ, Geurin TM, Chauhan A, Ried R, Nath A, Knapp PE, Hauser KF: Morphine increases astroglial and microglial activation in the brains of conditional HIV-Tat transgenic mice. Glia 2008, 56:1414-1427

15. Arango JC, Simmonds P, Brettle RP, Bell JE: Does drug abuse influence the microglial response in AIDS and HIV encephalitis? AIDS 2004, 18:S69-74

16. Marcario JK, Riazi M, Adany I, Kenjale H, Fleming K, Marquis J, Nemon O, Mayo MS, Yankee T, Narayan O, Cheney PD: Effect of morphine on the neuropathogenesis of SIVmac infection in Indian Rhesus Macaques. J Neuroimmune Pharmacol 2008, 3:12-25

17. Noel RJ, Jr., Kumar A: Virus replication and disease progression inversely correlate with SIV tat evolution in morphine-dependent and SIV/ SHIV-infected Indian rhesus macaques. Virology 2006, 346:127-138

18. Kumar R, Orsoni S, Norman L, Verma AS, Tirado G, Giavedoni LD, Staprans S, Miller GM, Buch SJ, Kumar A: Chronic morphine exposure causes pronounced virus replication in cerebral compartment and accelerated onset of AIDS in SIV/SHIV-infected Indian rhesus macaques. Virology 2006, 354:192-206

19. Chuang RY, Suzuki S, Chuang TK, Miyagi T, Chuang LF, Doi RH: Opioids and the progression of simian AIDS. Front Biosci 2005, 10:1666-1677

20. Donahoe RM, Falek A: Neuroimmunomodulation by opiates and other drugs of abuse: relationship to HIV infection and AIDS. Adv Biochem Psychopharmacol 1988, 44:145-158

21. Donahoe RM, O'Eil SP, Marsteller FA, Novembre FJ, Anderson DC, Lankford-Turner $\mathrm{P}$, McClure $\mathrm{HH}$ : Probable deceleration of progression of Simian AIDS affected by opiate dependency: studies with a rhesus macaque/SIVsmm9 model. J Acquir Immune Defic Syndr 2009, 50:241-249

22. Burdo TH, Katner SN, Taffe MA, Fox HS: Neuroimmunity, drugs of abuse, and neuroAIDS. J Neuroimmune Pharmacol 2006, 1:41-49

23. Hauser KF, El-Hage N, Buch S, Berger JR, Tyor WR, Nath A, BruceKeller AJ, and Knapp PE: Molecular targets of opiate drug abuse in neuroAIDS. Neurotox Res 2005, 8:63-80

24. El-Hage N, Gurwell JA, Singh IN, Knapp PE, Nath A, Hauser KF Synergistic increases in intracellular $\mathrm{Ca}^{2+}$, and the release of MCP-1, RANTES, and IL-6 by astrocytes treated with opiates and HIV-1 Tat. Glia 2005, 50:91-106

25. El-Hage N, Wu G, Wang J, Ambati J, Knapp PE, Reed J, Bruce-Keller A, Hauser KF: HIV Tat ${ }_{1-72}$ and opiate-induced changes in astrocytes promote chemotaxis of microglia through the expression of MCP-1 and alternative chemokines. Glia 2006, 53:132-146

26. Turchan-Cholewo J, Dimayuga FO, Gupta S, Keller JN, Knapp PE, Hauser KF, Bruce-Keller AJ: Morphine and HIV-Tat increase microglial-free radical production and oxidative stress: possible role in cytokine regulation. J Neurochem 2009, 108:202-215

27. El-Hage N, Bruce-Keller AJ, Yakovleva T, Bazov I, Bakalkin G, Knapp PE, Hauser KF: Morphine exacerbates HIV-1 Tat-induced cytokine production in astrocytes through convergent effects on $\left[\mathrm{Ca}^{2+}\right]_{\mathrm{i}}$, NFkappaB trafficking and transcription. PLoS ONE 2008, 3:e4093

28. Chauhan A, Turchan J, Pocernich C, Bruce-Keller A, Roth S, Butterfield DA, Major EO, Nath A: Intracellular human immunodeficiency virus Tat expression in astrocytes promotes astrocyte survival but induces potent neurotoxicity at distant sites via axonal transport. J Biol Chem 2003, 278:13512-13519

29. El-Hage N, Wu G, Ambati J, Bruce-Keller AJ, Knapp PE, Hauser KF: CCR2 mediates increases in glial activation caused by exposure to HIV-1 Tat and opiates. J Neuroimmunol 2006, 178:9-16

30. Feng P, Rahim RT, Cowan A, Liu-Chen LY, Peng X, Gaughan J, Meissler JJ, Jr., Adler MW, Eisenstein TK: Effects of mu, kappa or delta opioids administered by pellet or pump on oral Salmonella infection and gastrointestinal transit. Eur J Pharmacol 2006, 534:250-257

31. Livak KJ, Schmittgen TD: Analysis of relative gene expression data using real-time quantitative PCR and the 2[-delta delta $\mathrm{C}(\mathrm{T})]$ method. Methods 2001, 25:402-408

32. Hauser KF, McLaughlin PJ, Zagon IS: Endogenous opioid systems and the regulation of dendritic growth and spine formation. J Comp Neurol 1989, 281:13-22

33. Zhang SX, Holmberg EG, Geddes JW: Artifactual dendritic beading in rat spinal cord induced by perfusion with cold saline and paraformaldehyde. J Neurosci Methods 2007, 163:38-43

34. Tosi G, Meazza R, De Lerma Barbaro A, D'Agostino A, Mazza S, Corradin G, Albini A, Noonan DM, Ferrini S, Accolla RS: Highly stable oligomerization forms of HIV-1 Tat detected by monoclonal antibodies and requirement of monomeric forms for the transactivating function on the HIV-1 LTR. Eur J Immunol 2000, 30:1120-1126

35. Frankel AD, Bredt DS, Pabo CO: Tat protein from human immunodeficiency virus forms a metal-linked dimer. Science 1988, 240:70-73

36. Battaglia PA, Longo F, Ciotta C, Del Grosso MF, Ambrosini E, Gigliani F: Genetic tests to reveal TAT homodimer formation and select TAT homodimer inhibitor. Biochem Biophys Res Commun 1994, 201:701-708

37. Urbinati C, Nicoli S, Giacca M, David G. Fiorentini S, Caruso A, Alfano M, Cassetta L, Presta M, Rusnati M: HIV-1 Tat and heparan sulfate proteoglycan interaction: a novel mechanism of lymphocyte adhesion and migration across the endothelium. Blood 2009, 114:3335-3342

38. Duncan MJ, Bruce-Keller AJ, Conner C, Knapp PE, Xu R, Nath A Hauser KF: Effects of chronic expression of the HIV-induced protein, transactivator of transcription, on circadian activity rhythms in mice, with or without morphine. Am J Physiol Regul Integr Comp Physiol 2008, 295:R1680-R1687

39. Rice AP, Chan F: Tat protein of human immunodeficiency virus type 1 is a monomer when expressed in mammalian cells. Virology 1991, 185:451-454

40. Stauber RH, Pavlakis GN: Intracellular trafficking and interactions of the HIV-1 Tat protein. Virology 1998, 252:126-136

41. Frankel $A D$, Pabo $C O$ : Cellular uptake of the tat protein from human immunodeficiency virus. Cell 1988, 55:1189-1193

42. Robinson TE, Kolb B: Morphine alters the structure of neurons in the nucleus accumbens and neocortex of rats. Synapse 1999, 33:160-162

43. Liao D, Grigoriants OO, Wang W, Wiens K, Loh HH, Law PY: Distinct effects of individual opioids on the morphology of spines depend upon the internalization of mu opioid receptors. Mol Cell Neurosci 2007, 35:456-469

44. Liao D, Lin H, Law PY, Loh HH: Mu-opioid receptors modulate the stability of dendritic spines. Proc Natl Acad Sci USA 2005, 102: 1725-1730

45. Hebb DO: The organization of behavior: a neuropsychological theory. New York, Wiley 1949, pp. 1-335

46. Sa MJ, Madeira MD, Ruela C, Volk B, Mota-Miranda A, Paula-Barbosa MM: Dendritic changes in the hippocampal formation of AIDS patients: a quantitative Golgi study. Acta Neuropathologica (Berlin) 2004, 107:97-110

47. Masliah E, Ge N, Morey M, DeTeresa R, Terry RD, Wiley CA: Cortical dendritic pathology in human immunodeficiency virus encephalitis. Lab Invest 1992, 66:285-291

48. Luthert PJ, Montgomery MM, Dean AF, Cook RW, Baskerville A, Lantos PL: Hippocampal neuronal atrophy occurs in rhesus macaques following infection with simian immunodeficiency virus. Neuropathol Appl Neurobiol 1995, 21:529-534

49. Kaul M, Garden GA, Lipton SA: Pathways to neuronal injury and apoptosis in HIV-associated dementia. Nature 2001, 410:988-994

50. Nath A, Geiger J: Neurobiological aspects of human immunodeficiency virus infection: neurotoxic mechanisms. Prog Neurobiol 1998, 54:19-33

51. Hauser KF, McLaughlin PJ, Zagon IS: Endogenous opioids regulate 
dendritic growth and spine formation in developing rat brain. Brain Research 1987, 416:157-161

52. Hauser KF, Gurwell JA, Turbek CS: Morphine inhibits Purkinje cell survival and dendritic differentiation in organotypic cultures of the mouse cerebellum. Exp Neurol 1994, 130:95-105

53. Ricalde AA, Hammer RP, Jr: Perinatal opiate treatment delays growth of cortical dendrites. Neurosci Lett 1990, 115:137-143

54. Hammer RP, Ricalde AA, Seatriz JV: Effects of opiates on brain development. Neurotoxicology 1989, 10:475-483

55. Liao D, Grigoriants OO, Loh HH, Law PY: Agonist-dependent postsynaptic effects of opioids on miniature excitatory postsynaptic currents in cultured hippocampal neurons. J Neurophysiol 2007, 97:1485-1494

56. Robinson TE, Kolb B: Structural plasticity associated with exposure to drugs of abuse. Neuropharmacology 2004, 47:33-46

57. Oliva AA, Jr., Lam TT, Swann JW: Distally directed dendrotoxicity induced by kainic acid in hippocampal interneurons of green fluorescent protein-expressing transgenic mice. J Neurosci 2002, 22:8052-8062

58. Greenwood SM, Mizielinska SM, Frenguelli BG, Harvey J, Connolly $\mathrm{CN}$ : Mitochondrial dysfunction and dendritic beading during neuronal toxicity. J Biol Chem 2007, 282:26235-26244

59. Park JS, Bateman MC, Goldberg MP: Rapid alterations in dendrite morphology during sublethal hypoxia or glutamate receptor activation. Neurobiol Dis 1996, 3:215-227

60. Mattson MP, Haughey NJ, Nath A: Cell death in HIV dementia. Cell Death Differ 2005, 12 (Suppl 1):893-904

61. Li W, Huang Y, Reid R, Steiner J, Malpica-Llanos T, Darden TA, Shankar SK, Mahadevan A, Satishchandra P, Nath A: NMDA receptor activation by HIV-Tat protein is clade dependent. J Neurosci 2008 , 28:12190-12198

62. Perry SW, Norman JP, Litzburg A, Zhang D, Dewhurst S, Gelbard HA HIV-1 transactivator of transcription protein induces mitochondrial hyperpolarization and synaptic stress leading to apoptosis. J Immunol 2005, 174:4333-4344

63. Mattson MP, Gleichmann M, Cheng A: Mitochondria in neuroplasticity and neurological disorders. Neuron 2008, 60:748-766

64. Lin MT, Beal MF: Mitochondrial dysfunction and oxidative stress in neurodegenerative diseases. Nature 2006, 443:787-795

65. Maggirwar SB, Tong N, Ramirez S, Gelbard HA, Dewhurst S: HIV-1 Tat-mediated activation of glycogen synthase kinase-3beta contributes to Tat-mediated neurotoxicity. J Neurochem 1999, 73:578-586

66. Bellizzi MJ, Lu SM, Masliah E, Gelbard HA: Synaptic activity becomes excitotoxic in neurons exposed to elevated levels of platelet-activating factor. J Clin Invest 2005, 115:3185-3192

67. Bellizzi MJ, Lu SM, Gelbard HA: Protecting the synapse: evidence for a rational strategy to treat HIV-1 associated neurologic disease. J Neuroimmune Pharmacol 2006, 1:20-31

68. Zhang SX, Underwood M, Landfield A, Huang FF, Gison S, Geddes $\mathrm{JW}$ : Cytoskeletal disruption following contusion injury to the rat spinal cord. J Neuropathol Exp Neurol 2000, 59:287-296

69. Kim HJ, Martemyanov KA, Thayer SA: Human immunodeficiency virus protein Tat induces synapse loss via a reversible process that is distinct from cell death. J Neurosci 2008, 28:12604-12613

70. Kim BO, Liu Y, Ruan Y, Xu ZC, Schantz L, He JJ: Neuropathologies in transgenic mice expressing human immunodeficiency virus type 1 Tat protein under the regulation of the astrocyte-specific glial fibrillary acidic protein promoter and doxycycline. Am J Pathol 2003, 162:1693-1707

71. Markstein M, Pitsouli C, Villalta C, Celniker SE, Perrimon N: Exploiting position effects and the gypsy retrovirus insulator to engineer precisely expressed transgenes. Nat Genet 2008, 40:476-483

72. Mansour A, Fox CA, Akil H, Watson SJ: Opioid-receptor mRNA expression in the rat CNS: anatomical and functional implications. Trends Neurosci 1995, 18:22-29

73. Mansour A, Khachaturian H, Lewis ME, Akil H, Watson SJ: Anatomy of CNS opioid receptors. Trends Neurosci 1988, 11:308-314

74. Ruzicka BB, Thompson RC, Watson SJ, Akil H: Interleukin-1b-mediated regulation of mu-opioid receptor mRNA in primary astrocyteenriched cultures. J Neurochem 1996, 66:425-428

75. Ruzicka BB, Akil H: The interleukin-1beta-mediated regulation of proenkephalin and opioid receptor messenger RNA in primary astrocyte-enriched cultures. Neuroscience 1997, 79:517-524

76. Low KG, Melner MH: Expression of high levels of proenkephalin in an isolated glial cell type: inhibition by gamma interferon. Ann NY Acad Sci 1990, 594:475-478

77. McCarthy L, Wetzel M, Sliker JK, Eisenstein TK, Rogers TJ: Opioids, opioid receptors, and the immune response. Drug Alcohol Depend 2001, 62:111-123

78. Carr DJ, Rogers TJ, Weber RJ: The relevance of opioids and opioid receptors on immunocompetence and immune homeostasis. Proc Soc Exp Biol Med 1996, 213:248-257

79. Stein C, Schafer M, Machelska H: Attacking pain at its source: new perspectives on opioids. Nat Med 2003, 9:1003-1008

80. Turchan-Cholewo J, Dimayuga FO, Ding Q, Keller JN, Hauser KF Knapp PE, Bruce-Keller AJ: Cell-specific actions of HIV-Tat and morphine on opioid receptor expression in glia. J Neurosci Res 2008, 86:2100-2110

81. Buch SK, Khurdayan VK, Lutz SE, Knapp PE, El-Hage N, Hauser KF: Glial-restricted precursors: patterns of expression of opioid receptors and relationship to HIV-1 Tat and morphine susceptibility in vitro. Neuroscience 2007, 146:1546-1554

82. Rogers TJ, Peterson PK: Opioid G protein-coupled receptors: signals at the crossroads of inflammation. Trends Immunol 2003, 24:116-121

83. Kim E, Clark AL, Kiss A, Hahn JW, Wesselschmidt R, Coscia CJ, Belcheva MM: Mu- and kappa-opioids induce the differentiation of embryonic stem cells to neural progenitors. J Biol Chem 2006 281:33749-33760

84. Knapp PE, Itkis OS, Zhang L, Spruce BA, Bakalkin G, Hauser KF Opiate signaling in oligodendrocytes: possible autocrine effects on cell survival and development. Glia 2001, 35:156-165

85. Stiene-Martin A, Knapp PE, Martin K, Gurwell JA, Ryan S, Thornton SR, Smith FL, Hauser KF: Opioid system diversity in developing neurons, astroglia, and oligodendroglia in the subventricular zone and striatum: impact on gliogenesis in vivo. Glia 2001, 36:78-88

86. Chao CC, Gekker G, Hu S, Sheng WS, Shark KB, Bu DF, Archer S, Bidlack JM, Peterson PK: kappa opioid receptors in human microglia downregulate human immunodeficiency virus 1 expression. Proc Nat Acad Sci USA 1996, 93:8051-8056

87. Peterson PK, Molitor TW, Chao CC: The opioid-cytokine connection J Neuroimmunol 1998, 83:63-69

88. Eisenstein TK, Hilburger ME: Opioid modulation of immune responses: effects on phagocyte and lymphoid cell populations. J Neuroimmunol 1998, 83:36-44

89. DeLeo JA, Tanga FY, Tawfik VL: Neuroimmune activation and neuroinflammation in chronic pain and opioid tolerance/hyperalgesia. Neuroscientist 2004, 10:40-52

90. Adler MW, Geller EB, Rogers TJ, Henderson EE, Eisenstein TK Opioids, receptors, and immunity. Adv Exp Med Biol 1993, 335:13-20

91. Negro A, Tavella A, Facci L, Callegaro L, Skaper SD: Interleukin-1 beta regulates proenkephalin gene expression in astrocytes cultured from rat cortex. Glia 1992, 6:206-212

92. Fitting S, Zou S, Chen W, Vo P, Hauser KF, Knapp PE: Regional heterogeneity and diversity in cytokine and chemokine production by astroglia: differential responses to HIV-1 Tat, gp120, and morphine revealed by multiplex analysis. J Proteome Res 2010, 9:1795-1804

93. Narita M, Kuzumaki N, Miyatake M, Sato F, Wachi H, Seyama $Y$, Suzuki T: Role of delta-opioid receptor function in neurogenesis and neuroprotection. J Neurochem 2006, 97:1494-1505

94. Wallace DR, Dodson SL, Nath A, Booze RM: Delta opioid agonists attenuate TAT(1-72)-induced oxidative stress in SK-N-SH cells. Neurotoxicology 2006, 27:101-107

95. Chao D, Bazzy-Asaad A, Balboni G, Salvadori S, Xia Y: Activation of DOR attenuates anoxic $\mathrm{K}+$ derangement via inhibition of $\mathrm{Na}+$ entry in mouse cortex. Cereb Cortex 2008, 18:2217-2227

96. Zagon IS, McLaughlin PJ: Increased brain size and cellular content in infant rats treated with an opiate antagonist. Science 1983, 221:1179-1180 